\title{
European Patterns of Development in Historical Perspective
}

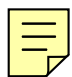

\section{ABSTRACT}

Europe provides a suitable scenario for testing empirical regularities of growth since, to a large extent, its countries share institutions, policies, and resource endowments. Patterns of development, which associate structural change with variations in GDP per head and population, are constructed for modern Europe (1850-1990) along the lines of Chenery and Syrquin's pathbreaking work. Thus, it is possible to discern whether a common set of development processes is observable for the whole continent and whether countries that had a late start exhibited, as suggested by Gerschenkron, a differential behaviour in terms of accumulation, resource allocation, and demographic transition. The results tend to confirm the different nature of latecomers' development.

Key words: Chenery and Syrquin, Gerschenkron, latecomers, modern Europe, patterns of development

'Quid rides? mutato nomine de te fabula narratur'

Horace, Satires, I, i, v. 69

The search for an optimal path of development, usually associated with the German Historical School, goes back to the Classical economists and can be traced back to the philosophers of the Enlightenment. ${ }^{1}$ Adam Smith suggested a stage approach to historical development, and Karl Marx twice quoted Horace's verses to emphasise the extent to which Britain's industrialising experience forecasted the future of Germany, by then, a latecomer. ${ }^{2}$ After World War II economists once more became interested in long-term growth and

1 Cf. O'Brien, D.P., The Classical Economists. Oxford: Oxford University Press 1975; Meier, G. \& Baldwin, R.E., Economic Development. Theory, History, Policy. New York: Wiley 1957; Schumpeter, J.A., History of Economic Analysis. Oxford: Oxford University Press 1954.

2 Smith, A., An Inquiry into the Nature and Causes of the Wealth of Nations. Chicago: University of Chicago Press 1976; Marx, K., Das Capital. London 1867. As Marx wrote in his preface, 'the industrially more developed country presents to the less developed country a picture of the latter's future'. 
turned to history in the search for a laboratory of natural experiments. ${ }^{3}$ Stylised facts, short cuts towards the optimal path of development, were explored during the Golden Age (1950-73) by a generation of applied, historically minded economists. ${ }^{4}$ One of their achievements was the construction of patterns of development that, in the Clark/Kuznets tradition, are rooted in stylised facts but lack an a priori model. ${ }^{5}$

Modern Europe provides a sound basis for testing empirical regularities of growth as it offers a consistent and homogeneous set of countries that have largely shared resource endowments, institutions, and economic policies. Nonetheless, the economic map of Europe over the last two centuries shows, as Gerschenkron expressively put it, 'a motley picture of countries varying with regard to the degree of their backwardness' and these initial differences have been 'of crucial significance for the nature of subsequent development' as economic structure, institutions, and ideologies all vary directly because of them. ${ }^{6}$

The purpose of this paper is to put the existence of a common path of development in modern Europe to the test with the help of the stylised patterns of structural change designed by Chenery and Syrquin. ${ }^{7}$ Nonetheless, the fact that countries that had a late start would follow a different path of development with respect to early starters will also be taken on board. ${ }^{8}$ The divergence between early starters and latecomers originates in their structure of production that results, in turn, from different institutions that substituted for the missing prerequisites of the first wave of industrialisation. ${ }^{9}$ In other words, we will examine whether latecomers utilised their 'advantage of backwardness' to leapfrog certain phases that early starters went through.

3 Cf. McCloskey, D.N., Does the past have useful economics?, in Enterprise and Trade in Victorian Britain. Essays in Historical Economics, Ed. D. N. McCloskey. London: George Allen and Unwin 1981.

4 Clark, C., The Conditions of Economic Progress. London: Macmillan, $2^{\text {nd }}$ edition 1957; Lewis, W.A. Economic Development with Unlimited Supplies of Labor, The Manchester School, vol. 22, 1954, 139-191; Kuznets, S., Modern Economic Growth: Rate, Structure and Spread. New Haven: Yale University Press 1966; Kuznets, S., Economic Growth of Nations. Cambridge, Mass.: Bellknap 1971; Chenery, H.B., Patterns of Industrial Growth, American Economic Review, 50, 1960, 624-654; Chenery, H.B. \& L. Taylor, Development Patterns: Among Countries and Over Time, Review of Economics and Statistics, vol. 50, 1968: 391-416; Rostow, W.W., Stages of Economic Growth. A NonCommunist Manifesto. Cambridge: Cambridge University Press 1960; Denison, E.F., Why Growth Rates Differ. Postwar Experience in Nine Countries. Washington, D.C.: The Brookings Institution 1967, pioneered a positive approach to the determinants of economic development.

5 That is, 'income-related changes for which the available evidence suggests considerable uniformity but for which there is yet no well defined body of theory'. Chenery, H.B. \& Syrquin, M., Patterns of Development, 1950-1970. Oxford: Oxford University Press 1975, 6.

6 Gerschenkron, A., Economic Backwardness in Historical Perspective. A Book of Essays. Cambridge: Harvard University Press 1962, 353. We cannot presume, therefore, that European countries went throughout similar stages of development á la Rostow. Cf. the pathbreaking work of O'Brien, P.K. \& C.. Keyder, Economic Growth in Britain and France (1780-1914). Two Paths to the Twentieth Century. London: Allen and Unwin 1978.

7 Chenery \& Syrquin, Patterns of Development.

8 Gerschenkron, Economic Backwardness.

9 As Chenery pointed out, latecomers exhibit significant differences that 'stem from the existence of the advanced countries as sources of technology, capital and manufactured imports, as well as markets for exports'. Chenery, H.B., Transitional Growth and World Industrialisation, in The International Allocation of Economic Activity, Ed. B. Ohlin et al. London: Macmillan 1977, 458. 
The existence of distinctive development patterns for different epochs in Modern European history, such as the liberal era prior to World War I, the neomercantilist interwar Years, and the post-World War II return to liberalism, will, therefore, be investigated by widening the scope of the paper to include both the nineteenth and the twentieth century. Furthermore, the existence of clusters of countries (Core or early starters and Periphery or latecomers) that shared structural features will be also explored and, thus, Gerschenkron's qualifications about the distinctive paths of development followed by early starters and latecomers will be revisited. ${ }^{10}$

Our results differ from those provided by Chenery and Syrquin, Crafts, and Branson, Guerrero and Gunter, not only because of the wider time coverage but also the allowance for regime changes through the estimation of 'adjusted' patterns. ${ }^{11}$ It is worth stressing that the historical approach in a relatively homogeneous region, such as Europe, that combines cross-section and time series data provides a superior choice to the usual cross-section analysis for the recent past, in which low-income countries are associated with early phases of development regardless (over-time and cross-country) of differences in preferences and tastes. ${ }^{12}$

\section{A Chenery and Syrquin Approach to European Development Patterns}

Modern economic development is seen as an identifiable process of growth and change, whose main features are the same across countries ${ }^{13}$ and can be defined as 'an interrelated set of long-run processes of structural transformation that accompany growth'. ${ }^{14}$ A structural transformation consists of a set of

10 The paper follows the lead established two decades ago by I. Adelman \& C. T. Morris, Patterns of Economic Growth, 1850-1914; or Chenery-Syrquin in historical perspective, in Economic Structure and Performance, Essays in Honor of Hollis B. Chenery, Ed. M. Syrquin, L Taylor \& L. E. Westphal. San Diego: Academic Press 1984; and N.F.R. Crafts, Patterns of Development in Nineteenth Century Europe, Oxford Economic Papers, vol. 36, 1984: 438-458, to cover earlier epochs than the statistically convenient late twentieth-century world, usually neglected by development economists. Crafts, Patterns of development, 449, already perceived in nineteenth-century Europe Gerschenkronian 'tendencies towards a different kind of structural change in the later developing countries'.

11 Chenery \& Syrquin, Patterns of Development; Crafts, Patterns of Development; Branson, W.H., I. Guerrero \& B.G. Gunter, Patterns of Development, 1970-1994, World Bank Working Paper 1998.

12 Cf. Branson, Guerrero \& Gunter, Patterns of development, for the latest substantive addition to this literature.

13 Solow, R.M., 'Comment' to H.B. Chenery 'Transitional Growth and World Industrialisation', in The International Allocation of Economic Activity, Ed. B. Ohlin et al. London: Macmillan 1977, 491. The rationale for this approach, as exposed by Kuznets, S., On Comparative Study of Economic Structure and Growth of Nations, in The Comparative Study of Economic Growth and Structure. New York: NBER 1959, 170, 'is conditioned on the existence of common, trans-national factors, and a mechanism of interaction among nations that will produce some systematic order in the way modern economic growth can be expected to spread around the world'.

14 Syrquin, M., Patterns of structural change, in Handbook of Development Economics, Ed. H. B. Chenery \& T. N. Srinivasan. Amsterdam: North-Holland 1988, 2 vols, I, 205. A more comprehensive definition of economic development has been put forward by Adelman \& Morris, Patterns of Economic Growth, 46, as 'the process of institutional transformation by which structural change is achieved and gains and losses are distributed'. 
changes in the composition of demand, production, trade, and employment, each reflecting different aspects of shifts in resource allocation that take place as income levels rise. Thus, a development pattern may be defined as any systematic variation in the economic and social structure associated with a rising level of per capita income. Structural changes interact with the pattern of productivity growth in a general equilibrium system to determine the rate and pace of growth. ${ }^{15}$

In the patterns of development framework, each country is treated as an integrated, interdependent component of the international economy. Such an assumption is acceptable in Modern Europe only after the mid-nineteenth century, once the basis of the liberal international order was established. By then, however, more than three centuries of mercantilism, warfare and experience with internal and imperial markets had left the countries of Europe at rather diverse levels of development.

The patterns of development approach has been subjected to systematic criticism. ${ }^{16}$ It has been argued that the Chenery-Syrquin equations are derived from an unspecified model of development in which we cannot tell supply from demand determinants. Moreover, development patterns do not reveal a unique path to industrialisation since comparative advantage, policy and institutions matter. A country's trade and production patterns, as Bhagwati reminded us, are 'the result of an interaction between the country's own endowments and demands and the rest-of-the-world's endowments and demands', a fact apparently not accounted for in the Chenery patterns. ${ }^{17}$ The challenge, therefore, would instead be to assess 'the ability of an economy to reach its full potential, that is, to come close to optimal growth' ${ }^{18}$ Another objection relates to the econometric approach as causality may run in either direction: from the level of per capita income to the structural variable or viceversa and, in fact, an endogeneity problem could arise as the structural variable associated with the per capita GDP level is often a conventional determinant of economic growth. ${ }^{19}$

In the development patterns, however, there is no implication that a single unique path, through which all economies have to pass, has to exist. On the contrary, Chenery and his associates were always aware that by treating development within a uniform framework, systematic differences in national

Syrquin, M., Growth and Structural Change in Latin America, Economic Development and Cultural Change, vol. 34, 1986: 433-454.

16 Cf. for instance, Diaz Alejandro, C., Review of Patterns of Development 1950-1970 by M. Chenery and M. Syrquin, Economic Journal, 86, 1976: 401-403. Williamson, J.G., The Constraints of Industrialization: Some Lessons of the First Industrial Revolution. Proceedings of the Eighth International Economic Association World Congress, New Delhi 1986 (mimeo) wrote, 'in uncritical moments we tend to gauge an economy's performance by its ability to replicate or even exceed those stylized patterns'.

17 Bhagwati, J.N., Comment to H. B. Chenery 'Transitional Growth and World Industrialization', in The International Allocation of Economic Activity, Ed. B. Ohlin et al. London: Macmillan 1977, 491.

18 Williamson, Constraints of Industrialization.

19 Cf. the discussion in Branson, Guerrero \& Gunter, Patterns of Development. 
development patterns would be identified. ${ }^{20}$ In fact, they distinguish between two components of a country's pattern of development: the normal effect of universal factors (which accounts for most of the observed structural variation among countries) and the effects of a country's individual history (which can be more readily evaluated after allowing for the uniform elements in each development pattern). ${ }^{21}$

A feasible way to approach historical reality is, as Gerschenkron put it, through the search for certain regularities or uniformities, and the analysis of deviations from the norm. ${ }^{22}$ Since development occurs with sufficient uniformity among countries to produce a consistent pattern of change in resource allocation, factor use, and other structural features as the level of per capita income rises, a set of basic processes restricted only by the lack of empirical evidence has been selected. ${ }^{23}$ All variables are expressed as shares (of GDP, total employment, etc.) since it is the relative variation that determines structural change. Shares are calculated at nominal prices since the decisions of individuals and firms are more meaningfully analysed at current, rather than at constant, prices. The development processes studied can be divided into three main categories: a) accumulation, which deals with the resources used to increase an economy's productive capacity, for which we have gathered information on stocks (literacy) and on increases in stocks (gross domestic investment and school enrolment); b) resource allocation, which interacting with accumulation, produces systematic changes in the composition of domestic demand, foreign trade, production and employment, as real product per head rises; c) demographic transition. ${ }^{24}$ Here they are summarised:

1. Domestic Demand (percentage of GDP): gross domestic investment, private consumption and government consumption.

2. Education: primary and secondary school enrolment (percentage of population aged 5 to 19) and literacy (percentage of population over 7 years old).

3. Output Structure (percentage of GDP): value added in agriculture, industry (including mining, construction and utilities) and services.

4. Labour Allocation (percentage of total labour force): labour force in agriculture, industry and services.

5. Foreign Trade (ratio to GDP): exports, imports, openness (exports plus imports), primary exports and manufactured exports.

20 As Chenery, H.B., Structural transformation: a program of research, in The State of Development Economics. Progress and Perspectives, Ed. G. Ranis \& T.P. Schultz. Oxford: Basil Blackwell 1986, 60, put it, 'the search for uniform features of development almost inevitably leads to a division of countries into more homogeneous groups'. Chenery \& Syrquin, Patterns of Development; 5 between the demand effects of rising income and the supply effect of changes in factor proportions and technology'. 
6. Urbanisation (percentage of population in towns of over 20,000 inhabitants).

7. Demographic transition: crude birth and death rates (per thousand inhabitants), gross fertility (children per woman), infant mortality (per thousand births) and net fertility. ${ }^{25}$

Data on structural change across Europe during 1850-1990 have been gathered mostly from national sources, in particular from reconstructed national accounts (see Appendix on sources) for three-year averages around years ending in 0 from 1850 to 1900; then, for significant benchmarks in the interwar period $(1913,1925,1929,1933,1938)$ and for years ending in 0 and 5 during 1950-1990. A major feature of the data set is that non-market economies have been excluded given the conceptual and data problems involved (different economic categories, low reliability, and, especially, a different set of incentives for economic agents). ${ }^{26}$ Countries included appear in Table 1.

GDP per head is expressed here in 1990 Geary-Khamis 'international' dollars and national series have been built by projecting backwards from 1990 levels using each country's growth rates (taken from historical national accounts). Regrettably, the resulting series suffer from a serious index number problem, since their economic meaning weakens as we move away from the 1990 benchmark. ${ }^{27}$

\section{Methodology}

In this section the econometric methods used for the construction of patterns of development are exposed. We start from the method designed by Chenery and Syrquin and since the statistical procedure has to be applied to a wide range of structural processes and countries, the scope for a more refined econometric specification is constrained by the availability of data. ${ }^{28}$

In addition to confirming the existence of patterns of development common to modern Europe, a major goal of this essay is to separate the effects of universal factors, common to all countries, from particular characteristics of each one, in order to highlight national deviations from the European patterns of development. I, therefore, assume that any indicator of structural change, $\mathbf{I}_{\mathrm{it}}$ for $\mathbf{i}=$ country, and $\mathbf{t}=$ time period, can be divided into two different parts:

25 Net fertility $=(1-$ infant mortality rate $) *$ gross fertility.

26 The choice of 1990 as the end year in this investigation is due to the fact that the demise of communism in Europe changed borders and was followed by a transition to the market in central and eastern European countries that were not included while they were command economies and accumulation and resource allocation were not ruled by market forces. Thus, this paper cover the late nineteenth century (1850-1913) and, to use Hobsbawn's expression, 'the short' twentieth century (1914-1990).

27 Prados de la Escosura, L., International Comparisons of Real Product, 1820-1990. An Alternative Data Set, Explorations in Economic History, vol. 37, 2000: 1-41.

28 Chenery \& Syrquin, Patterns of Development. Branson et al., Patterns of Development, faced the same constraint for the last quarter of the twentieth century. 
Table 1 Countries included in the regressions (1850-1990)

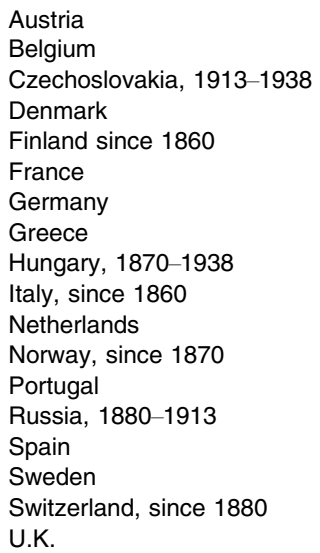

$$
I_{i t}=f_{1}\left[\alpha U_{i t}\right]+f_{2}\left[\beta_{i,} V_{i t}\right]
$$

where $\alpha$ is a $\mathbf{k} * \mathbf{1}$ vector of time and cross-country invariant parameters; $\mathbf{U}_{\mathbf{i t}}$ is a vector of explanatory variables representing the level of development, market size, economies of scale, etc. in country $\mathbf{i}$ at period $\mathbf{t} ; \boldsymbol{\beta}_{\mathbf{i}}$ is a time invariant but cross-country variant vector of parameters; and $\mathbf{V}_{\mathbf{i t}}$ represents a set of explanatory variables, including a stochastic disturbance (which incorporates war, political unification, etc.). $\mathbf{U}_{\mathbf{i t}}$ includes the explanatory variables used by Chenery and Syrquin, ${ }^{29}$ to which others for country size and a time-trend component have been added:

\section{(2) $\mathbf{U}_{\mathrm{it}}^{\prime}=\left[\mathbf{c}, \operatorname{LnY}_{\mathrm{it}},\left(\operatorname{LnY}_{\mathrm{it}}\right)^{2}, \mathbf{L n N}_{\mathrm{it}},\left(\operatorname{LnN}_{\mathrm{it}}\right)^{2}, \mathbf{M}_{\mathrm{it}}, \operatorname{LnSize}_{\mathrm{i}}, \operatorname{TREND}_{\mathrm{t}}\right]$}

where $\mathrm{c}$ is a constant term; $\mathbf{Y}_{\mathbf{i t}}$, real income per head; $\mathbf{N}_{\mathbf{i t}}$, population; $\mathbf{M}_{\mathbf{i t}}$, net imports as a share of GDP; Size $_{\mathbf{i}}$, country i's area in square kilometres; TREND $_{\mathbf{t}}$ time trend dummy.

Under these conditions, $f_{1}\left(\alpha, U_{i t}\right)$ will be the part of the structural variable $I_{i t}$ that can be explained by the pattern of development common to all countries, while the divergence of country $i$ from the pattern will be $\mathbf{f}_{\mathbf{2}}\left(\boldsymbol{\beta}_{\mathbf{i}}, \mathbf{V}_{\mathrm{it}}\right)$. Then, assuming that $\alpha$ exists amounts to accepting that a common pattern does exist. Next the necessary assumptions to estimate the patterns of development properly have to be established. We have preferred the semi-log to the double$\log$ formulation in order to retain the additive property for the different components of aggregates (i.e., the sectoral shares of output must add to 100). In addition, it will be assumed that $\mathrm{f}_{\mathbf{1}}\left(\alpha, \mathrm{U}_{\mathrm{it}}\right)=\alpha^{*} \mathrm{U}_{\mathrm{it}}$. Under these conditions, we have: 


$$
\begin{gathered}
\mathbf{I}_{\mathrm{it}}=\alpha_{0}+\alpha_{1} * \operatorname{LnY}_{\mathrm{it}}+\alpha_{2}{ }^{*} \operatorname{LnY}_{\mathrm{it}}^{2}+\alpha_{3}{ }^{*} \operatorname{LnN}_{\mathrm{it}}+\alpha_{4}{ }^{*} \operatorname{LnN}_{\mathrm{it}}^{2}+\alpha_{5}{ }^{*} \mathbf{M}_{\mathrm{it}} \\
+\alpha_{6}{ }^{*} \operatorname{LnSIZE}_{\mathrm{i}}+\alpha_{7}{ }^{*} \operatorname{TREND}_{\mathrm{i}}+\mathbf{f}_{2}\left(\boldsymbol{\beta}_{\mathrm{i}}, \mathbf{V}_{\mathrm{it}}\right)
\end{gathered}
$$

Income per head works as an overall index of development and as a measure of output. Population represents the market size and captures the effect of economies of scale and transport costs on patterns of production and trade. These effects are independent of the income level, since no correlation is expected between market size and level. In addition, quadratic terms are included to allow for non-linearities. In our sample, each country's population size changes substantially as our time coverage is of one and a half centuries, and a new country-size variable that represents the area of the country helps to control for this, while it works at the same time as a countrydummy. The time-trend variable should capture universal changes over time not associated with the other independent variables (e.g., institutions, policies, etc.) that affect all countries alike. The time-trend dummy eliminates all variation between time periods so that the original panel data sample can easily be treated like a simple pool of cross-section data, as regards the econometric approach.

The target now will be to estimate the $\left[\alpha_{0}, \alpha_{1}, \alpha_{2}, \ldots, \alpha_{7}\right]$ vector. For this estimate to be consistent, we will assume that there is no correlation between variables included in $\mathbf{U}_{\mathbf{i t}}$ and $\mathbf{V}_{\mathbf{i t}}$. This is a very strong assumption that may not be true in practice and, therefore, one must be very cautious when interpreting the econometric results. ${ }^{30}$ If such an assumption holds true, we will be able to isolate additively and consistently the part of the structural variable that can be explained by a common pattern of development, and obtain $\mathbf{f}_{2}\left(\boldsymbol{\beta}_{\mathbf{i}}, \mathbf{V}_{\mathrm{it}}\right)$ as a residual that measures the particular divergence of each country's structural indicator from the pattern.

The formulation described so far is what we will call the single pattern because the time-varying regressors are supposed to have homogeneous effects on each structural variable over the whole time span. A second and more historically relevant approach has been introduced to test and, in its case, to detect the existence of structural changes in the constant term and in the slopes of $\mathbf{L n Y}$ and $\mathbf{L n N}$ in different sub-periods of our sample. This method allows us to go beyond the time-trend dummy that stands for an exogenous uniform shift but is unable to discriminate between periods. ${ }^{31}$ The outcome is the adjusted pattern. Three historical periods were chosen to test structural breaks: the period prior to World War I, the interwar years, 19201938, and the post-World War II period up to 1990. To allow for different possibilities of structural change over these historical periods, dummy variables are defined in Table 2.

30 To avoid this problem, it could have been assumed that $\mathrm{V}_{\mathrm{it}}=\mathrm{V}_{\mathrm{i}}, \forall \mathrm{t}$ and $\mathrm{f}_{2}\left(\beta_{\mathrm{i}}, \mathrm{V}_{\mathrm{i}}\right)=\beta_{\mathrm{i}}{ }^{\prime *} \mathrm{~V}_{\mathrm{i}}$. This linear specification would permit the elimination of the term $\mathrm{f}_{2}\left(\beta_{\mathrm{i}}, \mathrm{V}_{\mathrm{i}}\right)$ taking deviations with respect to the mean in the time-varying dimension (within-group estimator). But, in that case, we would also get rid of $\mathrm{a}_{0}$. This would not present a major problem if we were sure that $\mathrm{a}_{0}$ is really a constant because, in such a case several estimation techniques could be used consistently. However, it is easy to guess that $a_{0}$ will present several structural changes in its long time-varying dimension, and testing this hypothesis is another goal of this essay. For such a reason, we finally decided to assume the lack of correlation between $\mathrm{U}_{\mathrm{it}}$ and $\mathrm{V}_{\mathrm{it}}$, and to go on with the initial specification. 
D13: value 1 from 1820 to 1913 , and 0 , thereafter.

D2090: value 0, 1820-1913; 1, 1920-1990.

D38: value 1, 1820-1938; 0, thereafter.

D5090: value 0, 1820-1938; 1, 1950-1990.

D2038: value 0, 1820-1913 and 1950-1990; 1, 1920-1938.

$\operatorname{LnY} 13=\mathrm{D} 13^{\star} \ln Y$

$\operatorname{LnY} 38=\mathrm{D} 38^{*} \operatorname{LnY}$

$\operatorname{LnY} 2038=\mathrm{D} 2038^{*} \operatorname{LnY}$

$\operatorname{LnN13}=\mathrm{D} 13^{*} \ln N$

$\operatorname{LnN} 38=\mathrm{D} 38^{*} \mathrm{LnN}$

$\mathrm{LnN2038}=\mathrm{D} 2038^{*} \mathrm{LnN}$

\section{Regression Analysis}

The econometric results for both single and adjusted patterns deserve some comments. ${ }^{32}$ The main finding is that existence of patterns of development common to modern European countries appears to be confirmed. Adjusted R-squared and statistical tests indicate so. If accumulation and resource allocation processes are examined we can find, for example, that as regards the composition of demand, both coefficients of income and population present the expected sign, as income is negatively related to consumption (total and private) and positively to domestic investment, while the opposite occurs with population. Size and trend dummies also correlate positively to investment and negatively to consumption (only to private consumption for the time trend). Larger countries appear to invest more at given levels of income and investment rates increase as time goes by, regardless of income (while the opposite happens to private consumption). In the adjusted patterns, a dummy variable for the slope of $\mathbf{L n Y}$ in different periods allows us to locate structural breaks, from which it emerges that for investment, as could be expected, the estimated coefficient of income reached the highest value in the post-World War II era, and the lowest in the interwar years. The same happens (but with a negative sign) to private consumption, with larger absolute values for the post1950 period, and a positive coefficient for the interwar years.

The supply side offers the expected correlation between income and population on the one hand, and agricultural shares in output and employment on the other, i.e., negative for income and positive for population, while a positive one appears for industry shares in output and employment with respect to income. ${ }^{33}$ When the estimated coefficient of the quadratic term shows an opposite sign to that of the linear term, it means that the relation

32 The regression results are provided in Prados de la Escosura, L., Gerschenkron Revisited. European Patterns of Development in Historical Perspective, Universidad Carlos III de Madrid Working Papers 05-79 (10) 2005, available from: http://docubib.uc3m.es/WORKINGPAPERS/WH/wh057910.pdf

33 When quadratic terms exist, the resulting overall value has been obtained by weighting coefficients for quadratic and non-quadratic terms with income values ranging from 1,000 to 15,000 US dollars at 1990 prices (PPP). No clear relationship appears for population and industry shares in output and employment (positive for the single pattern, negative for the adjusted pattern). For services shares, there is a negative correlation for population, while for income it is negative only for the single pattern. 
between structural change and income level attenuates as GDP per head rises. The time-trend and size dummies show a positive sign for agricultural shares in output and employment, independently of the level of income (while the opposite is observed for industry). In the case of agriculture, the estimated coefficient for income, negative, is higher in absolute terms for the period prior to World War I (as the adjusted coefficients reveal).

Urbanisation, as expected, is positively related to income and population and also to net imports (a proxy for capital inflow), while it is negatively correlated to the country's size. Human capital indicators (school enrolment and literacy) consistently show positive correlations with income and negative ones with population and size. The time trend appears to be positive for primary and secondary schooling although the income coefficient was higher before World War I.

The demographic transition shows the expected negative relation to income for birth and death (including infant mortality). For the adjusted pattern, fertility (both gross and net) is positively related to income. Such a result suggests that findings for the post-1960 world, i.e., a negative relation between net fertility and income, ${ }^{34}$ cannot be simply extrapolated to earlier periods in which economic development helped to reduce infant mortality and, therefore, increased net fertility. A clear negative time trend appears for all demographic indicators.

Finally, foreign trade indicators unanimously show a positive relation to income (with larger estimated coefficients as time goes by), and a negative one to population and size, as well as a negative time trend that suggests that latecomers tend to be less open at similar income levels. The positive link between population and manufacturing exports is the exception and might suggest a Linder scenario of representative demand, in which producing industrial goods for home consumption appears as a prerequisite for exporting them. ${ }^{35}$

\section{Normal Structural Variation with the Level of Development}

Table 3 presents the structural transformation that occurs as real GDP per head grows. Simulations are provided for all development processes within an income range from 1,000 to 12,000 dollars (at 1990 'international' prices), when most of the transition from a pre-industrial to a modern society occurs. Three development processes are considered, i.e., accumulation, resource allocation and demographic transition. Together with the normal structural change associated with a rise in GDP per head, growth elasticities have been computed for given levels of per capita income and its changes (Table 4).

Most development processes were half-completed at early stages of development, somewhere in between 3,000 and 4,000 dollars, and four-fifths of the

34 Barro, R.J., Economic Growth in a Cross Section of Countries, Quarterly Journal of Economics, vol. 106, 1991: 407-443. 
Table 3 Normal variation in economic structure with the level of development. Predicted values at different income levels, 1990 GearyKhamis \$

\begin{tabular}{|c|c|c|c|c|c|c|c|c|c|c|c|c|}
\hline Processes & 1000 & 2000 & 3000 & 4000 & 5000 & 6000 & 7000 & 8000 & 9000 & 10000 & 11000 & 12000 \\
\hline \multicolumn{13}{|l|}{$\begin{array}{l}\text { Accumulation } \\
\text { Investment (\% GDP) }\end{array}$} \\
\hline Saving & 6.5 & 11.0 & 13.7 & 15.6 & 17.1 & 18.3 & 19.3 & 20.2 & 21.0 & 21.6 & 22.3 & 22.8 \\
\hline Investment & 8.3 & 12.4 & 14.8 & 16.5 & 17.8 & 18.9 & 19.8 & 20.6 & 21.3 & 21.9 & 22.5 & 23.0 \\
\hline Capital inflow & 1.8 & 1.4 & 1.1 & 0.9 & 0.7 & 0.6 & 0.5 & 0.4 & 0.3 & 0.3 & 0.2 & 0.2 \\
\hline \multicolumn{13}{|l|}{ Education (\%) } \\
\hline Literacy & 51.1 & 65.8 & 74.3 & 80.4 & 85.1 & 89.0 & 92.2 & 95.1 & 97.6 & 99.8 & 100.0 & 100.0 \\
\hline Schooling & 31.7 & 41.1 & 46.6 & 50.5 & 53.6 & 56.1 & 58.2 & 60.0 & 61.6 & 63.0 & 64.3 & 65.5 \\
\hline \multicolumn{13}{|l|}{ Resource allocation } \\
\hline \multicolumn{13}{|l|}{ Demand (\% GDP) } \\
\hline Private consumption & 87.7 & 80.1 & 75.7 & 72.5 & 70.0 & 68.0 & 66.3 & 64.9 & 63.6 & 62.4 & 61.4 & 60.4 \\
\hline Govt. consumption & 5.8 & 8.8 & 10.6 & 11.9 & 12.9 & 13.7 & 14.4 & 14.9 & 15.5 & 15.9 & 16.3 & 16.7 \\
\hline \multicolumn{13}{|l|}{ Production (\% GDP) } \\
\hline Agriculture & 44.6 & 33.2 & 26.4 & 21.7 & 18.0 & 15.0 & 12.4 & 10.2 & 8.3 & 6.5 & 5.0 & 3.5 \\
\hline Industry & 26.4 & 29.8 & 31.8 & 33.2 & 34.3 & 35.2 & 36.0 & 36.7 & 37.2 & 37.8 & 38.2 & 38.7 \\
\hline Services & 29.0 & 37.0 & 41.8 & 45.1 & 47.7 & 49.8 & 51.6 & 53.1 & 54.5 & 55.7 & 56.8 & 57.8 \\
\hline \multicolumn{13}{|l|}{ Labour Force (\%) } \\
\hline Agriculture & 65.7 & 50.1 & 41.0 & 34.6 & 29.5 & 25.5 & 22.0 & 19.0 & 16.4 & 14.0 & 11.9 & 9.9 \\
\hline Industry & 21.1 & 25.9 & 28.7 & 30.6 & 32.2 & 33.4 & 34.5 & 35.4 & 36.2 & 36.9 & 37.6 & 38.2 \\
\hline Services & 13.2 & 24.0 & 30.3 & 34.8 & 38.3 & 41.1 & 43.5 & 45.6 & 47.4 & 49.1 & 50.5 & 51.9 \\
\hline \multicolumn{13}{|l|}{ Urbanisation (\%) } \\
\hline Urban population & 12.6 & 22.6 & 28.5 & 32.7 & 35.9 & 38.5 & 40.8 & 42.7 & 44.4 & 45.9 & 47.3 & 48.6 \\
\hline \multicolumn{13}{|c|}{ Relative Labour Productivity (\%) } \\
\hline Agriculture & 68.0 & 66.2 & 64.5 & 62.7 & 60.9 & 58.8 & 56.4 & 53.7 & 50.5 & 46.5 & 41.6 & 35.3 \\
\hline
\end{tabular}


Table 3 (Continued)

\begin{tabular}{|c|c|c|c|c|c|c|c|c|c|c|c|c|}
\hline Processes & 1000 & 2000 & 3000 & 4000 & 5000 & 6000 & 7000 & 8000 & 9000 & 10000 & 11000 & 12000 \\
\hline \multicolumn{13}{|l|}{ Trade (\% GDP) } \\
\hline Exports of goods & 11.6 & 15.4 & 17.6 & 19.1 & 20.3 & 21.4 & 22.2 & 22.9 & 23.6 & 24.1 & 24.6 & 25.1 \\
\hline Primary exports & 11.6 & 10.9 & 10.0 & 9.4 & 8.9 & 8.6 & 8.2 & 7.9 & 7.7 & 7.5 & 7.3 & 7.1 \\
\hline Manufactured exports & 0.0 & 4.5 & 7.6 & 9.7 & 11.4 & 12.8 & 14.0 & 15.0 & 15.9 & 16.6 & 17.3 & 18.0 \\
\hline Imports of goods & 10.9 & 16.0 & 18.9 & 21.1 & 22.7 & 24.0 & 25.2 & 26.2 & 27.0 & 27.8 & 28.5 & 29.1 \\
\hline Openness & 20.5 & 31.4 & 36.5 & 40.2 & 43.0 & 45.4 & 47.4 & 49.1 & 50.6 & 51.9 & 53.1 & 54.2 \\
\hline \multicolumn{13}{|l|}{ Demographic transition } \\
\hline Birth rate (o/oo) & 33.2 & 27.7 & 24.5 & 22.2 & 20.4 & 19.0 & 17.7 & 16.7 & 15.7 & 14.9 & 14.1 & 13.5 \\
\hline Death rate (o/oo) & 22.2 & 18.6 & 16.4 & 14.9 & 13.7 & 12.8 & 11.9 & 11.2 & 10.6 & 10.0 & 9.5 & 9.1 \\
\hline $\begin{array}{l}\text { Rate natural } \\
\text { Increase (o/oo) }\end{array}$ & 11.0 & 9.1 & 8.1 & 7.3 & 6.7 & 6.2 & 5.8 & 5.5 & 5.1 & 4.9 & 4.6 & 4.4 \\
\hline Fertility & 4.6 & 3.9 & 3.4 & 3.1 & 2.9 & 2.7 & 2.5 & 2.3 & 2.2 & 2.1 & 2.0 & 1.9 \\
\hline Infant mortality (o/oo) & 186.8 & 136.8 & 107.5 & 86.7 & 70.6 & 57.4 & 46.3 & 36.6 & 28.1 & 20.5 & 13.6 & 7.3 \\
\hline Net fertility [Fertility* [1 -Infmort/1000]] & 3.8 & 3.3 & 3.0 & 2.8 & 2.6 & 2.5 & 2.4 & 2.2 & 2.1 & 2.0 & 2.0 & 1.9 \\
\hline
\end{tabular}


Table 4 Normal variation in growth elasticities with the level of development. Predicted values at different income levels, 1990 Geary-Khamis \$

\begin{tabular}{|c|c|c|c|c|c|c|}
\hline \multirow[b]{2}{*}{ Processes } & \multicolumn{4}{|c|}{ Point Elasticities* } & \multicolumn{2}{|c|}{ Discrete Elasticities** } \\
\hline & 1000 & 2000 & 4000 & 8000 & $1000-4000$ & $4000-800$ \\
\hline \multicolumn{7}{|l|}{$\begin{array}{l}\text { Accumulation } \\
\text { Investment (\% GDP) }\end{array}$} \\
\hline Saving & & & & & 0.632 & 0.373 \\
\hline $\begin{array}{l}\text { Investment } \\
\text { Capital inflow }\end{array}$ & 0.71 & 0.48 & 0.36 & 0.29 & 0.496 & 0.320 \\
\hline \multicolumn{7}{|l|}{ Education (\%) } \\
\hline Literacy & 0.41 & 0.32 & 0.26 & 0.22 & 0.327 & 0.242 \\
\hline Schooling & 0.43 & 0.33 & 0.27 & 0.23 & 0.336 & 0.249 \\
\hline \multicolumn{7}{|l|}{$\begin{array}{l}\text { Resource allocation } \\
\text { Demand (\% GDP) }\end{array}$} \\
\hline Private consumption & -0.13 & -0.14 & -0.15 & -0.17 & -0.137 & -0.160 \\
\hline Govt. consumption & 0.80 & 0.50 & 0.37 & 0.30 & 0.518 & 0.324 \\
\hline \multicolumn{7}{|l|}{ Production (\% GDP) } \\
\hline Agriculture & -0.37 & -0.50 & -0.76 & -01.62 & -0.520 & -1.089 \\
\hline Industry & 0.23 & 0.20 & 0.18 & 0.16 & 0.165 & 0.145 \\
\hline Services & 0.40 & 0.31 & 0.26 & 0.22 & 0.319 & 0.236 \\
\hline \multicolumn{7}{|l|}{ Labour Force (\%) } \\
\hline Agriculture & -0.34 & -0.45 & -0.65 & -1.18 & -0.463 & -0.840 \\
\hline Industry & 0.33 & 0.27 & 0.23 & 0.20 & 0.268 & 0.210 \\
\hline Services & 1.18 & 0.65 & 0.45 & 0.34 & 0.699 & 0.390 \\
\hline \multicolumn{7}{|l|}{ Urbanisation (\%) } \\
\hline Urban population & 1.15 & 0.64 & 0.44 & 0.34 & 0.688 & 0.385 \\
\hline \multicolumn{7}{|l|}{ Trade (\% GDP) } \\
\hline Exports of goods & 0.47 & 0.35 & 0.28 & 0.24 & 0.361 & 0.262 \\
\hline Primary exports & - & - & - & - & -0.152 & -0.251 \\
\hline Manufactured exports & - & 1.67 & 0.78 & 0.50 & 1.639 & 0.629 \\
\hline Imports of goods & 0.55 & 0.38 & 0.28 & 0.23 & 0.477 & 0.312 \\
\hline Openness & 0.62 & 0.41 & 0.32 & 0.26 & 0.486 & 0.289 \\
\hline \multicolumn{7}{|l|}{ Demographic transition } \\
\hline Birth rate $(0 / 00)$ & -0.24 & -0.29 & -0.36 & -0.48 & -0.290 & -0.411 \\
\hline Death rate $(\mathrm{o} / 00)$ & -0.24 & -0.28 & -0.36 & -0.47 & -0.288 & -0.412 \\
\hline Fertility & -0.24 & -0.28 & -0.35 & -0.48 & -0.285 & -0.431 \\
\hline Infant mortality (o/oo) & -0.39 & -0.53 & -0.83 & -1.97 & -0.554 & -1.244 \\
\hline $\begin{array}{l}\text { Net fertility [Fertility* } \\
{[1-\text { Infmort/1000]] }}\end{array}$ & -0.20 & -0.23 & -0.27 & -0.34 & -0.220 & -0.348 \\
\hline
\end{tabular}

${ }^{*}$ Computed as $\varepsilon_{\mathrm{x}_{\mathrm{t}}, \mathrm{y}_{\mathrm{t}}}=\frac{\alpha_{1}+2 \alpha_{2} \ln \mathrm{Y}_{\mathrm{t}}}{\mathrm{x}_{\mathrm{t}}}$, where $\alpha_{1}$ and $\alpha_{2}$ are the coefficients for lineal and quadratic terms of income $\left(\mathrm{Y}_{\mathrm{t}}\right)$ in the regression, and $\mathrm{x}_{\mathrm{t}}$ is the predicted value corresponding to the level of income at which the elasticity is being computed.

**Elasticities with respect to GDP per head computed from Table 3 by dividing log differences: $\left[\mathrm{Ln} \mathrm{X}_{\mathrm{T}} / \mathrm{X}_{0} / \mathrm{Ln} \mathrm{Y}_{\mathrm{T}} / \mathrm{Y}_{0}\right]$ 
transformation had occurred at an income of 8,000 dollars. ${ }^{36}$ The interesting implication is that growth in post-World War II Europe, the period from where most economic theorists derived their stylised facts, is weakly related to resource allocation. ${ }^{37}$

In the accumulation process, proxies for physical and human capital have been considered. Information on GDP expenditure components permitted us to derive net imports of goods and services as a residual that, in turn, proxied capital net inflow, and, as a result, to derive the rate of national saving (expressed as a share of GDP). The comparison between investment and saving suggests a life-cycle behaviour, in which domestic saving is lower than investment demand at initial levels of the transition, with the gap closing as income rises. In both cases, the share of GDP increases as income rises, multiplying over the total income range considered by 3.5 in the case of saving ( 2.4 times up to $\$ 4,000$, the mid-transition point), and by 2.8 in the case of investment (2.0 up to $\$ 4,000)$, that is, representing a gain of 16.3 percentage points for saving, and 14.7 for investment ( 9.1 and 8.2 by $\$ 4,000$, when half the transition was completed). Proximate indices for human capital also show large increases, multiplying by 2 over the whole transition ( 1.6 by half of it), that is, up to 52.5 percentage points for literacy, and 33.8 for schooling, (29.3 and 18.8 up to $\$ 4,000$ ).

Associated with growth, there are structural shifts in the allocation of resources. Resource allocation interacts with factor endowments, economic policies and productivity growth to condition the path of development. Overall consumption fell by 20 per cent throughout the transition (10 per cent when half of it was achieved); that is, declining from over 90 per cent of aggregate demand to around three-fourths. Trends in private and government consumption followed, however, opposite directions, while the former fell by 31 per cent, the latter rose by 188 per cent $(-17$ and 105 per cent, respectively, over the first half of the transition). In percentage points, the variations represent 27.3 percentage points of decline for private and 10.9 of rise for public consumption ( -15.2 and 6.1 by half the transition).

On the supply side, a decline occurs in agriculture's shares in output and employment, while, for industry and services, there is an increase. It is worth mentioning that absolute increases are more noticeable in the shares of services (28.8 and 38.7 percentage points gained for output and employment, respectively, over the transition) than for industry (12.1 and 17.1, respectively), in particular, at higher income levels (over $\$ 4,000$ ). Agriculture's supremacy in output and employment disappears by $\$ 3,000$ and $\$ 4,000$, respectively. Interestingly enough, the proportional change implied by the transition differs from output to employment. It means that relative average labour productivity (that is, the ratio of each sector's share in output to that in employment) differs across sectors and, consequently, that efficiency improvements in the use of labour do not proceed at the same pace across sectors. In agriculture, a sharper

36 Pro-memoria, A per capita income of $\$ 4,000$ was reached by the U.K. in the 1890 s, and by France in the mid-1920s; a level of $\$ 8,000$ was reached by the UK or Germany in the early 1960 s; and $\$ 12,000$ was the income of France and Germany in the early 1970s. Maddison, A., The World Economy. Paris: OECD 2006

37 Such an empirical fact reinforced perhaps the neoclassical assumption that adjustments within the economy were immediate and frictionless. 
decline can be noticed for output share $(-41.1$ percentage points) than for employment share $(-55.8)$ (where a relative and, then, an absolute decline is experienced), which explains why the productivity gap widens as income rises. The lagged shift of labour out of agriculture due to the low mobility of the workforce, as it is the case when surplus labour in agriculture exists, helps to explain the productivity gap. Besides, partial productivity differences appear in most industrialisation experiences as investment and technological change occur more often in modern industry and services. ${ }^{38}$ Had all sectors the same production function, average labour productivity would equalise across them, given the same factor prices and complete resource mobility for all. Data constraints, however, do not allow the addressing of differentials in marginal productivity. A caveat to be made about relative labour productivity derives from the weakness of statistical data for employment in agriculture. In fact, at lower income levels, when the division of labour is not widely diffused yet, figures for the economically active population in agriculture (the main historical source for employment) tend to be over-exaggerated, as part-time labourers in industry and services tend to register under their main professions, e.g., farmers and, hence, figures for industry and services are understated. ${ }^{39}$

The share of population living in towns of over 20,000 inhabitants is the arbitrary threshold used here to assess the degree of urbanisation. A rapid increase in urbanisation takes place as income rises. A multiplier of 3.9 applies for the entire transition (2.6 for half of it), representing a rise of 36 percentage points (20 up to $\$ 4,000$ ). Besides, a decline in the proportion of agricultural labour within rural population (measured as the ratio of the agricultural share in total employment to the rural share in total population) occurs as GDP per head improves, suggesting that people living in the countryside tend to work increasingly outside agriculture as economic growth proceeds (from three quarters to one-fifth over the transition).

Development patterns for international trade help us to search for the sources of a country's comparative advantage and its changes as income grows. Historically, natural resource endowments, factor proportions and economic policies have conditioned trade specialisation. Examination of trade patterns shows a close link between the rise in GDP per head and that of the ratio of trade to GDP (a gain of 33.7 percentage points for openness, that is, exports plus imports), though the gain of imports exceeds that of exports. A possible explanation for the latter would be that as their income grows, countries become competitive in services, like nineteenth-century Britain, or attractive to foreign capital, like Spain between the 1850 s and the 1880 s. ${ }^{40}$ Changes in

Cf. Chenery \& Syrquin, Patterns of Development, 48.

39 Cf. Federico, G., Feeding the World. An Economic History of Agriculture, 1800-2000. Princeton: Princeton University Press 2005, and O'Brien, P.K. \& Prados de la Escosura, L., Agricultural Productivity and European Industralization, 1890-1980, Economic History Review, vol. 45, 1992: 514 536. Adjustment for actual days worked would further reduce the size of labour force in agriculture. Cf. Prados de la Escosura, L. \& Rosés, J.R., The Sources of Long-run Growth in Spain, 1850-2000, CEPR Discussion Paper 6189, for an exploration of the Spanish case.

40 Imlah, A.H., Economic Elements in the Pax Britannica. Studies in British Foreign Trade in the XIX ${ }^{\text {th }}$ Century. Harvard: Harvard University Press 1958; Prados de la Escosura, L., La posición internacional de la economía española, 1850-1935: nueva evidencia sobre la balanza de pagos, Universidad Carlos III 2007 (mimeo) 
comparative advantage from primary production to manufacturing are revealed by the composition of exports as income grows. Manufactured exports exceed those of primary goods at incomes of around \$4,000. Meanwhile, industry's share of GDP becomes larger than agriculture's at $\$ 3,000$. Such a lag suggests that in Europe, the emergence of a domestic market for industrial goods preceded that of foreign markets.

Finally, the demographic transition suggests a decline in both birth and death rates, in which the former experienced a deeper absolute fall, resulting in a slowing down in the rate of natural increase (by 6.6 percentage points), as income per head improves. Meanwhile, a decline in gross fertility is softened in net terms by the more rapid reduction in infant mortality.

So far only tendencies have been pointed out. Table 4 provides a more precise measurement of the responsiveness of structural transformation to changes in GDP per head for each development process. Elasticities have been computed both at a given level of per capita income (point estimates) and for income changes (discrete estimates), covering most of the transition from a preindustrial to a modern economy. In both estimates the lower the income level, the higher the value of the coefficient for growth elasticity, with the exception of those cases in which a negative relationship exists, where the opposite occurs. Differences in the structural response to increases in income are worth noticing. Both measures of (absolute) elasticities are higher, at lower income levels, for investment and government consumption, the share of services in total employment and urbanisation and manufactured exports, while the opposite occurs for agriculture's shares in output and employment, fertility (gross and net), infant mortality and crude birth and death rates.

\section{Revisiting Gerschenkron: Early Starters' and Latecomers' Development Patterns}

Up to this point, the discussion has been carried out on the basis of development patterns common to Modern Europe over one and a half centuries. However, when one and a half centuries is being considered, distinctive structural behaviour during different historical periods should be expected. The adjusted patterns of development allow for historical differences in structural change across different phases (from the mid-nineteenth century up to World War I, in the interwar years, and in the post-World War II era) and, therefore, help to distinguish the features of early starters and latecomers. A similar approach to the one used in the construction of average single patterns has been followed for the adjusted patterns. As an illustration, the patterns of development and growth elasticities are presented for the pre-World War I era in Table 5 and Table 6 . For the sake of simplicity, only the $\$ 1,000-\$ 4,000$ income range has been considered, as most European countries had not reached the upper level by 1913 .

Gerschenkron provided a set of propositions that can be tested with the help of the adjusted development patterns. ${ }^{41}$ Thus, he asserted that, the more

41 Gerschenkron, Economic Backwardness. This is done, however, at the risk of confusing the notion of 'backwardness' with that of 'lateness'. 
Table 5 Pre-1914 normal variation in economic structure with the level of development. Predicted values at different income levels, 1990 Geary-Khamis \$

\begin{tabular}{|c|c|c|c|c|c|c|c|}
\hline Processes & 1000 & 1500 & 2000 & 2500 & 3000 & 3500 & 4000 \\
\hline \\
\hline \multirow{2}{*}{\multicolumn{8}{|c|}{$\begin{array}{l}\text { Investment (\% GDP) } \\
\text { Saving }\end{array}$}} \\
\hline & & & & & & & \\
\hline $\begin{array}{l}\text { Investment } \\
\text { Capital inflow }\end{array}$ & 8.8 & 10.1 & 11.1 & 11.8 & 12.4 & 12.9 & 13.3 \\
\hline \multicolumn{8}{|l|}{ Education (\%) } \\
\hline Literacy & 33.7 & 50.7 & 62.8 & 72.2 & 79.8 & 86.3 & 91.9 \\
\hline Schooling & 28.2 & 34.9 & 39.6 & 43.3 & 46.3 & 48.8 & 51.0 \\
\hline \multicolumn{8}{|l|}{$\begin{array}{l}\text { Resource allocation } \\
\text { Demand (\% GDP) }\end{array}$} \\
\hline $\begin{array}{l}\text { Demand (\% GDP) } \\
\text { Private consumption }\end{array}$ & 84.7 & 83.1 & 82.0 & 81.2 & 80.5 & 79.9 & 79.4 \\
\hline Govt. consumption & 6.2 & 6.6 & 6.9 & 7.1 & 7.3 & 7.5 & 7.6 \\
\hline \multicolumn{8}{|l|}{ Production (\% GDP) } \\
\hline Agriculture & 47.9 & 40.5 & 35.3 & 31.2 & 27.9 & 25.1 & 22.7 \\
\hline Industry & 25.5 & 27.2 & 28.3 & 29.3 & 30.0 & 30.7 & 31.2 \\
\hline Services & 26.6 & 32.3 & 36.4 & 39.5 & 42.1 & 44.2 & 46.1 \\
\hline \multicolumn{8}{|l|}{ Labour Force (\%) } \\
\hline Agriculture & 67.6 & 56.4 & 48.5 & 42.3 & 37.3 & 33.0 & 29.3 \\
\hline Industry & 17.4 & 22.6 & 26.2 & 29.0 & 31.3 & 33.3 & 35.0 \\
\hline Services & 15.0 & 21.0 & 25.3 & 28.7 & 31.4 & 33.7 & 35.7 \\
\hline \multicolumn{8}{|l|}{ Urbanisation (\%) } \\
\hline Urban population & 7.7 & 16.4 & 22.7 & 27.6 & 31.5 & 34.9 & 37.8 \\
\hline \multicolumn{8}{|c|}{ Relative Labour Productivity (\%) } \\
\hline Agriculture & 70.8 & 71.8 & 72.8 & 73.8 & 74.8 & 76.0 & 77.2 \\
\hline \multicolumn{8}{|l|}{ Trade (\% GDP) } \\
\hline Exports of goods & 9.8 & 14.7 & 18.3 & 21.0 & 23.3 & 25.2 & 26.8 \\
\hline Primary exports & 9.8 & 11.5 & 12.1 & 12.5 & 13.0 & 13.3 & 13.5 \\
\hline Manufactured exports & 0.0 & 3.2 & 6.2 & 8.5 & 10.3 & 11.9 & 13.3 \\
\hline Imports of goods & 6.8 & 12.5 & 16.4 & 19.6 & 22.1 & 24.2 & 26.1 \\
\hline Openness & 16.6 & 27.2 & 34.7 & 40.6 & 45.4 & 49.4 & 52.9 \\
\hline \multicolumn{8}{|l|}{ Demographic transition } \\
\hline Birth rate $(\mathrm{o} / \mathrm{oo})$ & 34.6 & 32.1 & 30.4 & 29.0 & 27.8 & 26.9 & 26.1 \\
\hline Death rate (o/oo) & 24.1 & 22.6 & 21.5 & 20.6 & 19.9 & 19.3 & 18.8 \\
\hline Rate natural increase $(\mathrm{o} / \mathrm{oo})$ & 10.5 & 9.5 & 8.9 & 8.4 & 7.9 & 7.6 & 7.3 \\
\hline Fertility & 4.7 & 4.5 & 4.3 & 4.2 & 4.1 & 4.0 & 3.9 \\
\hline Infant mortality (o/০o) & 194.8 & 174.0 & 159.3 & 147.9 & 138.5 & 130.6 & 123.9 \\
\hline $\begin{array}{l}\text { Net fertility [fertility* } \\
{[1-\text { Infmort/1000]] }}\end{array}$ & 3.8 & 3.7 & 3.6 & 3.6 & 3.5 & 3.5 & 3.4 \\
\hline
\end{tabular}

backwards a country is, a) the faster the growth of industrial output; b) the more intense the stress on the size of both industrial plant and enterprise; c) the greater the stress upon producers' goods; d) the stronger the pressure on private consumption levels; e) the greater the role of institutional factors in promoting industrialisation (banks, the State), and f) the less active the role of 
Table 6 Pre-1914 normal variation in growth elasticities with the level of development. Predicted values at different income levels, 1990 Geary-Khamis \$

\begin{tabular}{|c|c|c|c|c|}
\hline \multirow[b]{2}{*}{ Processes } & \multicolumn{3}{|c|}{ Point Elasticities* } & \multirow{2}{*}{$\frac{\text { Discrete Elasticities ** }}{1000-4000}$} \\
\hline & 1000 & 2000 & 4000 & \\
\hline \multicolumn{5}{|l|}{$\begin{array}{l}\text { Accumulation } \\
\text { Investment (\% GDP) }\end{array}$} \\
\hline Saving & & & & - \\
\hline $\begin{array}{l}\text { Investment } \\
\text { Capital inflow }\end{array}$ & 0.37 & 0.29 & 0.24 & 0.298 \\
\hline \multicolumn{5}{|l|}{ Education (\%) } \\
\hline Literacy & 1.24 & 0.67 & 0.46 & 0.724 \\
\hline Schooling & 0.58 & 0.41 & 0.32 & 0.427 \\
\hline \multirow{2}{*}{\multicolumn{5}{|c|}{$\begin{array}{l}\text { Resource allocation } \\
\text { Demand (\% GDP) }\end{array}$}} \\
\hline & & & & \\
\hline Private consumption & -0.05 & -0.05 & -0.05 & -0.047 \\
\hline Govt. consumption & 0.17 & 0.15 & 0.14 & 0.147 \\
\hline \multicolumn{5}{|l|}{ Production (\% GDP) } \\
\hline Agriculture & -0.38 & -0.52 & -0.80 & -0.539 \\
\hline Industry & 0.18 & 0.16 & 0.15 & 0.146 \\
\hline Services & 0.53 & 0.39 & 0.31 & 0.397 \\
\hline \multicolumn{5}{|l|}{ Labour Force (\%) } \\
\hline Agriculture & -0.41 & -0.57 & -0.94 & -0.603 \\
\hline Industry & 0.72 & 0.48 & 0.36 & 0.504 \\
\hline Services & 1.00 & 0.59 & 0.42 & 0.626 \\
\hline \multicolumn{5}{|l|}{ Urbanisation (\%) } \\
\hline Urban population & 2.82 & 0.96 & 0.57 & 1.148 \\
\hline \multicolumn{5}{|l|}{ Trade (\% GDP) } \\
\hline Exports of goods & 1.25 & 0.67 & 0.46 & 0.726 \\
\hline Primary exports & - & - & - & 0.231 \\
\hline Manufactured exports & - & 1.64 & 0.77 & 1.866 \\
\hline Imports of goods & 2.31 & 0.96 & 0.60 & 0.970 \\
\hline Openness & 1.58 & 0.76 & 0.50 & 0.836 \\
\hline \multicolumn{5}{|l|}{ Demographic transition } \\
\hline Birth rate (o/oo) & -0.18 & -0.20 & -0.24 & -0.203 \\
\hline Death rate (o/oo) & -0.16 & -0.18 & -0.20 & -0.179 \\
\hline Fertility & -0.12 & -0.14 & -0.15 & -0.135 \\
\hline Infant mortality (o/oo) & -0.96 & -0.32 & -0.41 & -0.326 \\
\hline Net fertility [Fertility* [1 -Infmort/1000]] & -0.09 & -0.09 & -0.10 & -0.080 \\
\hline
\end{tabular}

${ }^{*}$ Computed as $\varepsilon_{\mathrm{x}_{\mathrm{t}}, \mathrm{y}_{\mathrm{t}}}=\frac{\alpha_{1}+2 \alpha_{2} \ln \mathrm{Y}_{\mathrm{t}}}{\mathrm{x}_{\mathrm{t}}}$, where $\alpha_{1}$ and $\alpha_{2}$ are the coefficients for lineal and quadratic terms of income $\left(Y_{t}\right)$ in the regression, and $x_{t}$ is the predicted value corresponding to the level of income at which the elasticity is being computed.

${ }^{\star \star}$ Elasticities with respect to GDP per head computed from Table 5 by dividing log differences: $\left[\operatorname{Ln} X_{T} / X_{0} / \operatorname{Ln} Y_{T} / Y_{0}\right]$ 
agriculture in industrialisation, that is, its provision of a market for industry by rising labour productivity. ${ }^{42}$

Unfortunately, only some of Gerschenkron's propositions about European development can be subjected to quantitative testing. ${ }^{43}$ The evidence presented here provides a preliminary test if we associate hypothesis a) with the size (and the increases) in the share of industry in output and employment; hypotheses b), c) and d) with the shares of GDP allocated to investment and private consumption, respectively; hypothesis e) with the share of GDP assigned to government consumption, and, finally, hypothesis $\mathrm{f}$ ) with the productivity gap and the relative size of agriculture in GDP and labour force.

From the comparison between pre-1914 Europe (Table 5) and the average single patterns of development for Modern Europe (1850-1990) (Table 3) with those obtained for developing countries in the Golden Age (1950-70) by Chenery and Syrquin, some interesting findings can be reported. ${ }^{44}$ As regards propositions b) and c), accumulation of both human and physical capital proceeded at a different pace before and after the Great War. Pre-1914 investment was lower than in Modern Europe as a whole, except at very low income levels. The contrast with developing countries shows a similar trend but at a lower level for Modern Europe (Figure 1). ${ }^{45}$ School enrolment was also lower in pre-1914 Europe at the same income levels, a fact associated with the larger role of government in the provision of services (health or education) as we move into the twentieth century, as is confirmed by the evidence on developing countries (Figure 2). Literacy also exhibits the same pattern at low levels of per capita GDP but reversed the pattern as income went up (Figure 3). Thus, lower investment rates in physical and human capital at similar income levels for nineteenth-century Europe lend indirect support to Gerschenkron's contention that latecomers to industrialisation emphasised producers' goods.

Differences between the pre-1914 period and the entire period considered (1850-1990) for resource allocation processes offer an answer to propositions d) and e). Thus, prior to 1914, the expenditure composition shows a higher (overall) consumption above $\$ 2,000$, with the share of private consumption larger (Figure 4) and that of government consumption smaller (Figure 5) above $\$ 1,000$. Latecomers, including post-World War II developing countries, hence

42 Gerschenkron, Economic Backwardness, 353-354. A critical assessment of Gerschenkron's views can be found in O'Brien, P.K., Do we have a Typology for the Study of European Industrialization in the XIXth Century?, Journal of European Economic History, vol. 15, 1986: 291-333. Gerschenkron's views are examined in the light of research during the late twentieth century in Sylla, R. \& G. Toniolo, Eds., Patterns of European Industrialization. The Nineteenth Century. London: Routledge 1992.

Unfortunately some of Gerschenkron's propositions are left aside in this quantitative but oversimplified exercise, including the role of investment banks or even that of the state.

Chenery \& Syrquin, Patterns of Development, computed patterns of development using U.S. dollars of 1964 obtained with trading exchange rates and they did it again in a later paper, this time using 1980 dollars (Syrquin, M. \& H. Chenery, Three Decades of Industrialization, World Bank Economic Review, vol. 3, 1989:2, 145-181). This reduces the comparability with our estimates in dollars adjusted for the purchasing power parity. As Syrquin and Chenery, Three decades of industrialization, 150, point out, 'differences across countries in incomes converted at [trading] exchange rates tend to exaggerate the real differences in income'. In order to carry out the comparison with Chenery and Syrquin, Patterns of Development, estimates we re-scaled their income levels to 1990 U.S. dollars using the U.S. implicit GDP deflator. 
Figure 1 Investment (\% GDP) in pre-1914 Europe, modern Europe and developing countries.

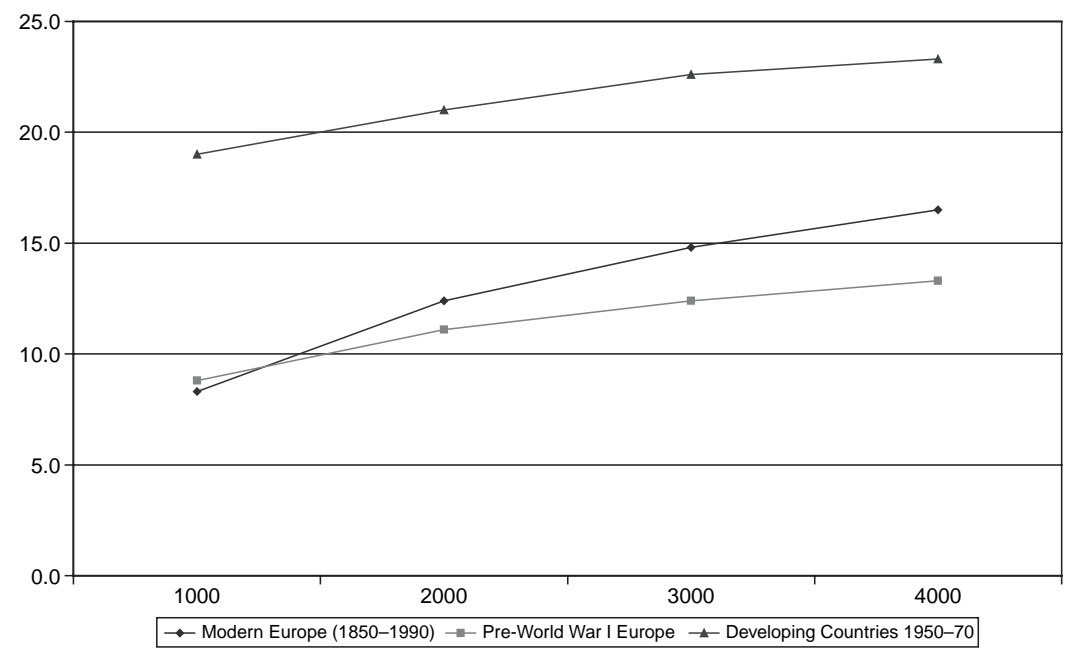

suffer from a higher pressure on private consumption while public consumption, usually correlated to the state's activist role, was larger, as Gerschenkron asserted.

The supply side shows noticeable differences for the pre-1914 patterns and provides responses to propositions a) and $\mathbf{f}$ ). Before the Great War, European agriculture presents a larger share of GDP for any income level (Figure 6) and a

Figure 2 Education enrolment (\%) in pre-1914 Europe, modern Europe and developing countries.

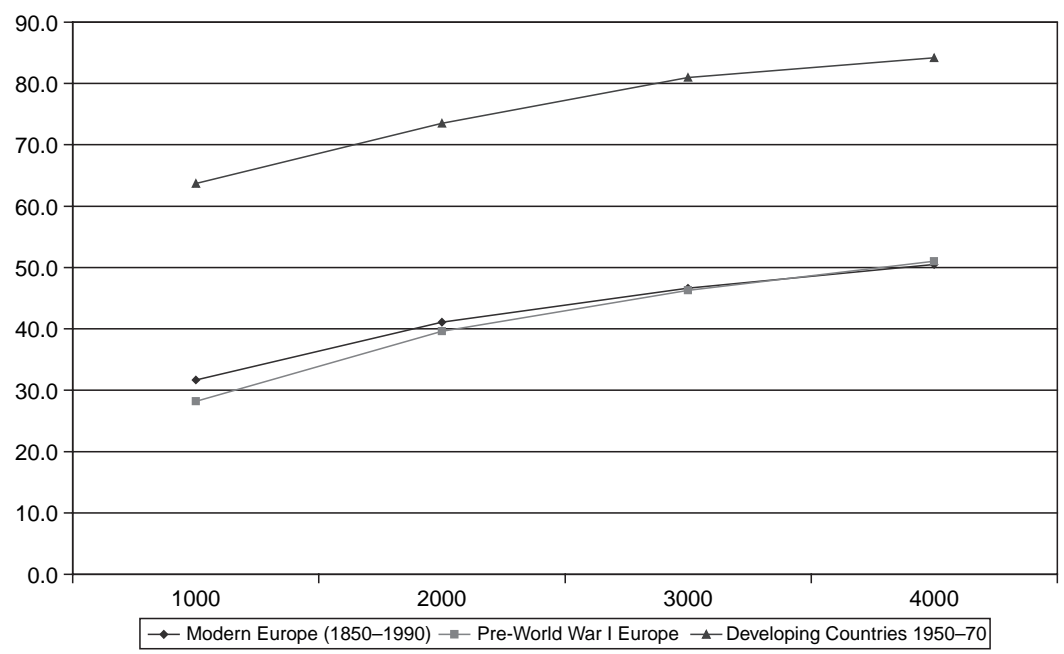


Figure 3 Literacy (\%) in pre-1914 europe and modern Europe.

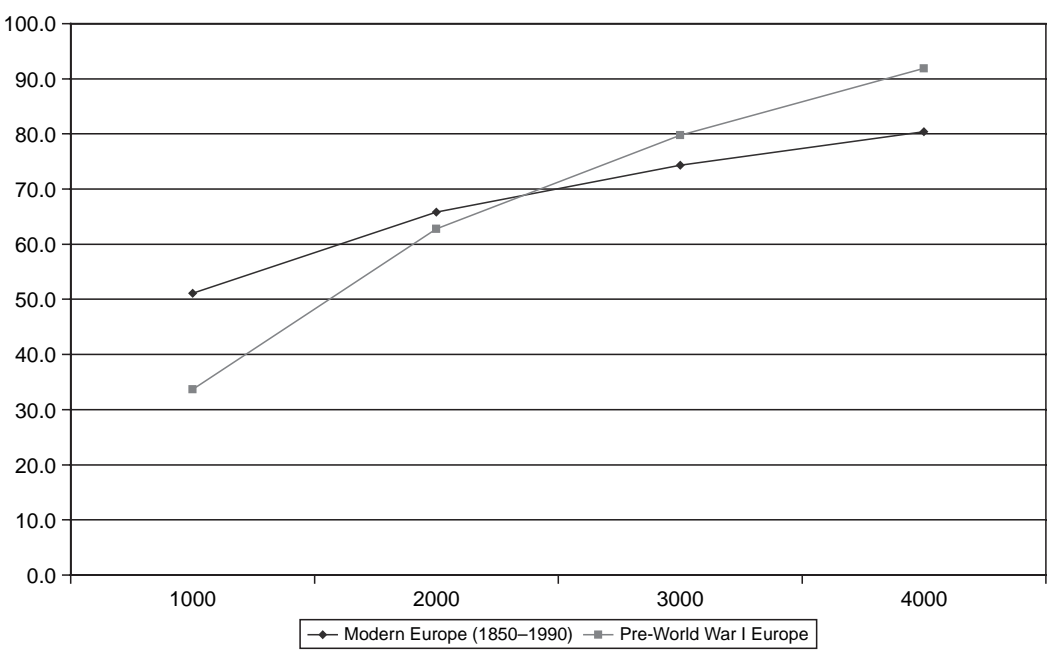

smaller share of the labour force above a $\$ 1,000$ income (Figure 7), than Modern Europe as a whole and developing countries after 1950. As a result, a lower productivity gap appears and tends to close as income rises. In other words, the lagged shift of labour out of agriculture and the higher productivity gap (Figure 8) confirm Gerschenkron's contention that latecomers' agriculture had a less active role in economic growth.

Figure 4 Private consumption (\% GDP) in pre-1914 Europe, modern Europe and developing countries.

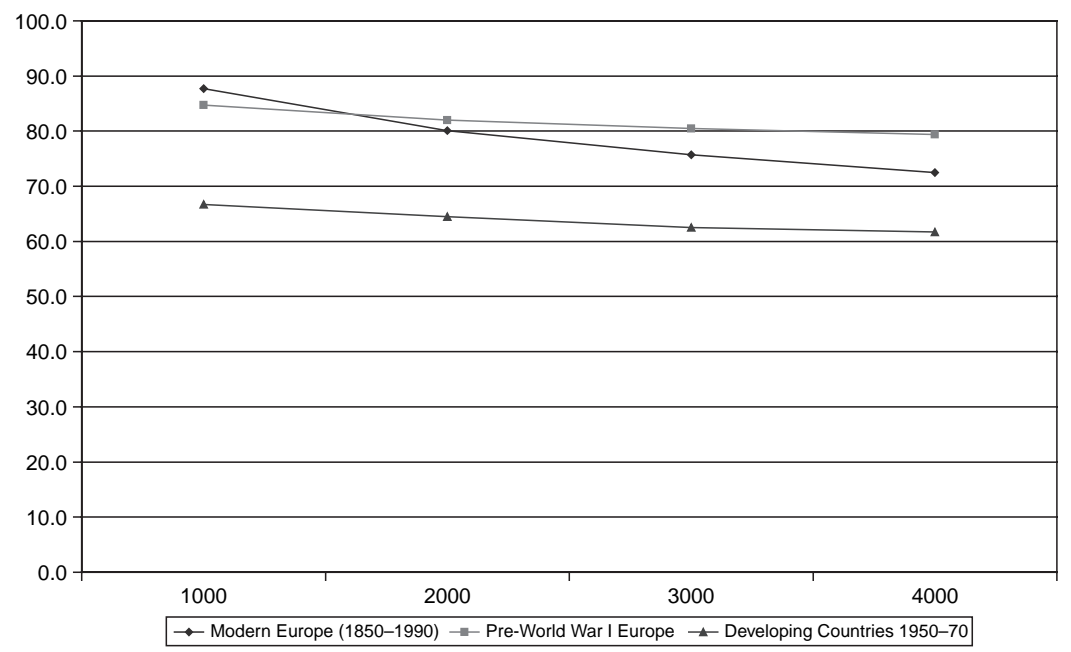


Figure 5 Government consumption (\% GDP) in pre-1914 Europe, modern Europe and developing countries.

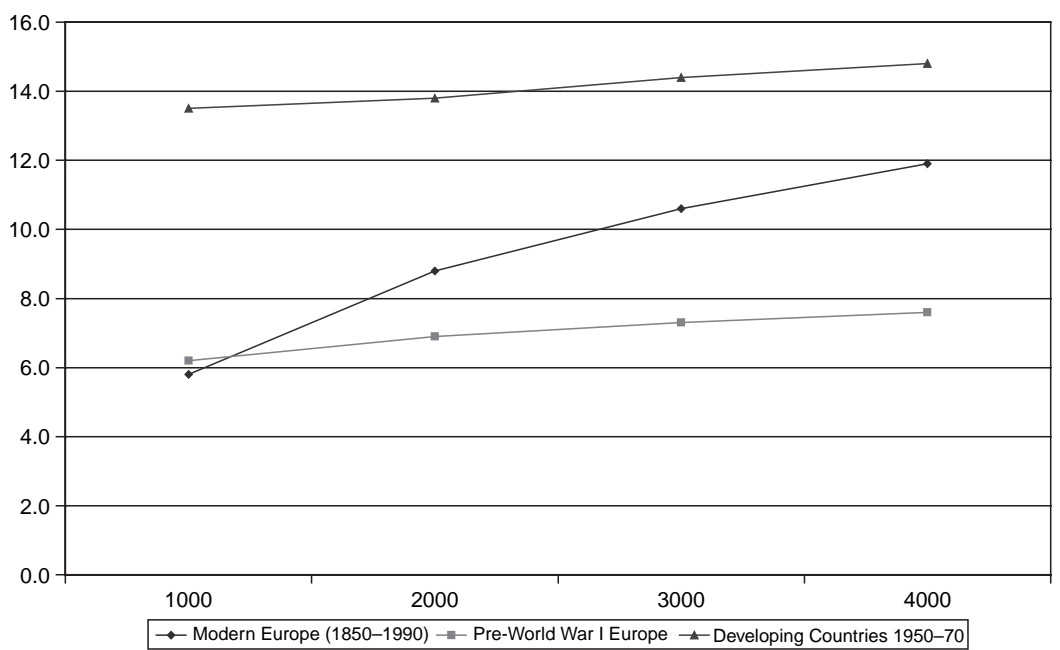

Lower shares of GDP for industry and services (the latter up to \$3,000) and higher shares of employment (over $\$ 1,000$ in the case of industry though not in the case of services in post-1950 developing countries) complete a more balanced labour allocation prior to the Great War than in later periods. Furthermore, in the pre-1914 era a more urbanised society as income grows

Figure 6 Agriculture (\% GDP) in pre-1914 Europe, modern Europe and developing countries.

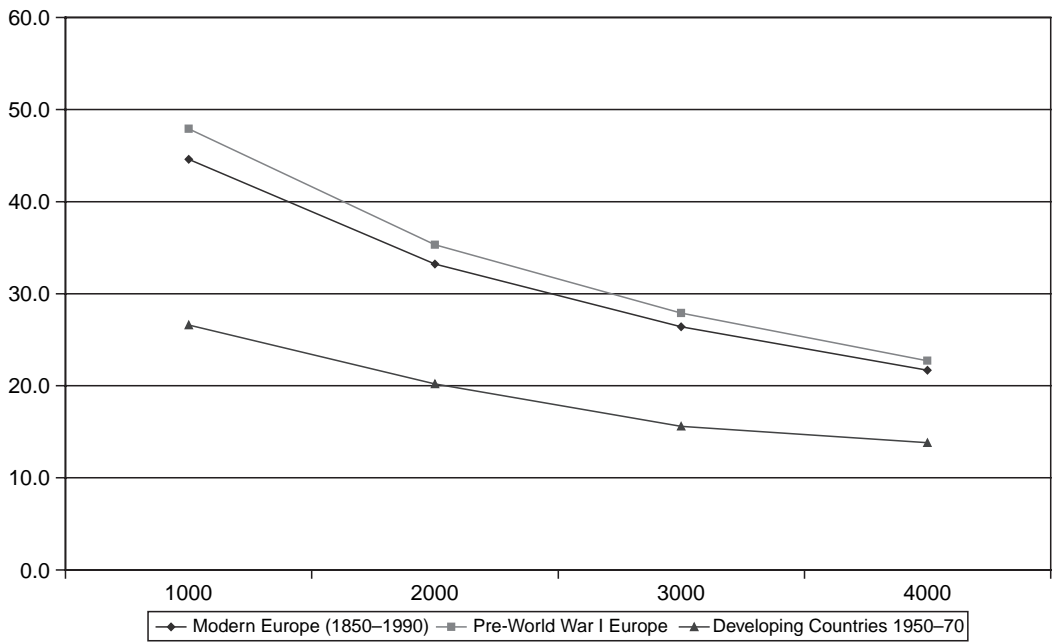


Figure 7 Agriculture (\% EAP) in pre-1914 Europe, modern Europe and developing countries.

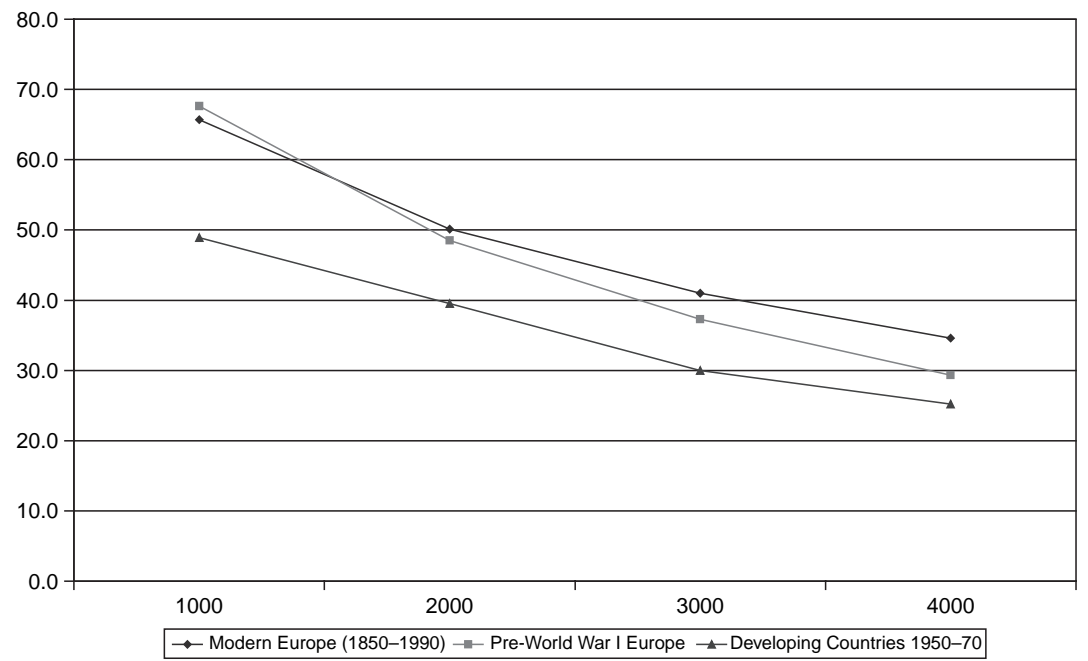

Figure 8 Relative agricultural average productivity in pre-1914 Europe, modern Europe and developing countries (average labour productivity in the economy $=1$ ).

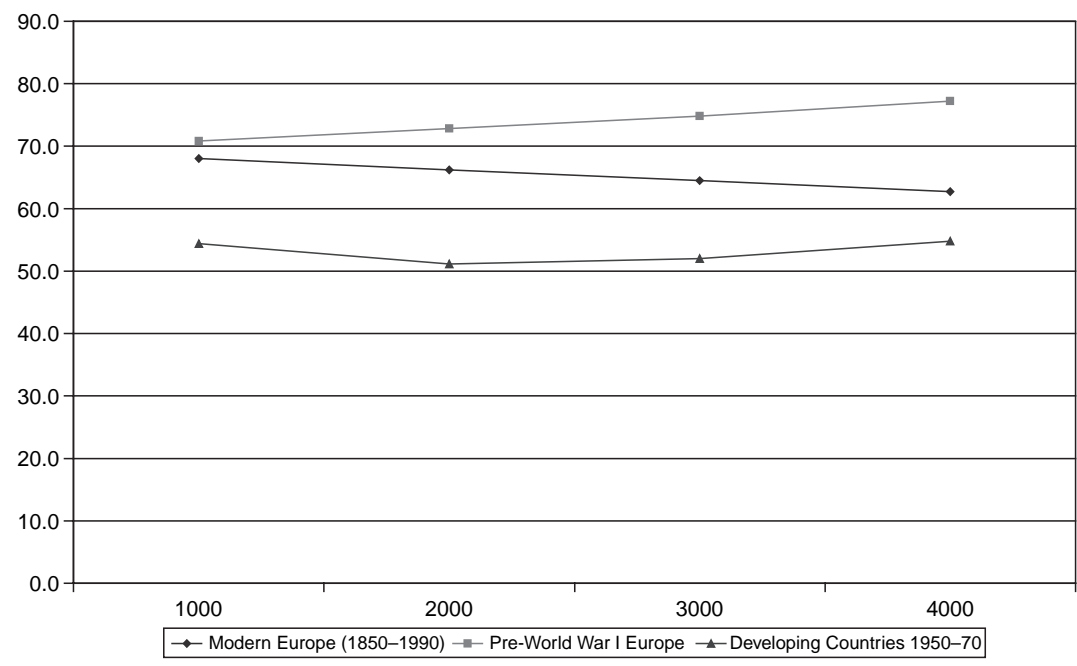


Figure 9 Urbanisation rate (\%) in pre-1914 Europe and modern Europe.

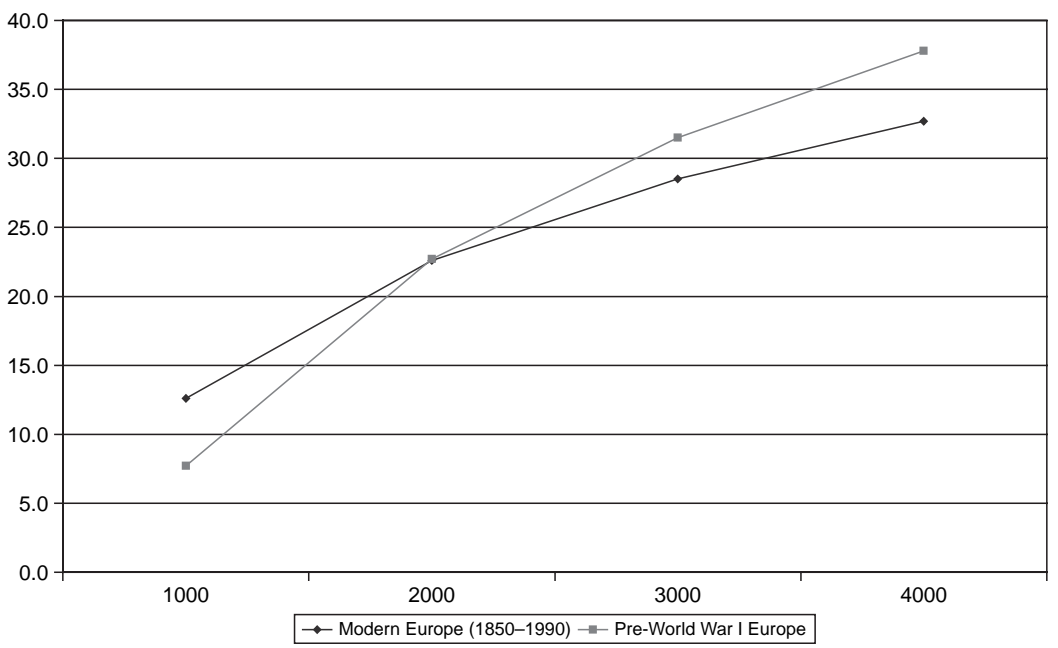

(above \$2,000) (Figure 9) and a rural population less dependent on agriculture appear at the same levels of income. However, as contended by Gerschenkron, a more intense industrial growth is observed in the case of latecomers whose relative industrial output grew faster within the same income range.

Differences in international trade also appear between the patterns of development of pre-1914 Europe and Modern Europe, as the former exhibits a more open economy (over $\$ 1,000$ ) as would be expected during the first globalisation (Figure 10) in which the larger share of manufacturing exports reveals its comparative advantage (Figure 11). The systematic commodity trade surplus of the early starters, in contrast with the deficit of the latecomers (Figure 12), points to a higher investment demand than domestic saving in the case of latecomers both in Modern Europe and in post-1950 developing countries, and can be illustrated for the cases of Britain, France and Spain in the nineteenth century. ${ }^{46}$

Higher birth and death rates, and slightly lower population pressure below $\$ 4,000$, plus higher fertility (Figure 13) and infant mortality (Figure 14), are the main demographic differences exhibited by the comparison between pre-1914 and Modern Europe (1850-1990) when compared with average, single patterns. The lower fertility in the case of latecomers does not seem to match higher investment in human capital (Figure 2 and 3), as suggested in the new growth literature, ${ }^{47}$ and points to the increasing role of government as provider of social services during the twentieth century. The contrast with post-1945

46 Imlah, Pax Britannica; Prados de la Escosura, Posición internacional; Levy-Leboyer, M., La balance des paiements et l'exportation des capitaux français, in La position international de la France Aspects économiques et financiers XIX ${ }^{e}-X X^{e}$ siècles, Ed. M. Lévy-Leboyer. Paris, Editions EDHESS 1977.

47 Barro, R.J., Determinants of Economic Growth. A Cross-Country Empirical Study. Cambridge, MA: M.I.T. Press 1997, 22-25. 
Figure 10 Exports/GDP ratio in pre-1914 Europe, modern Europe and developing countries.

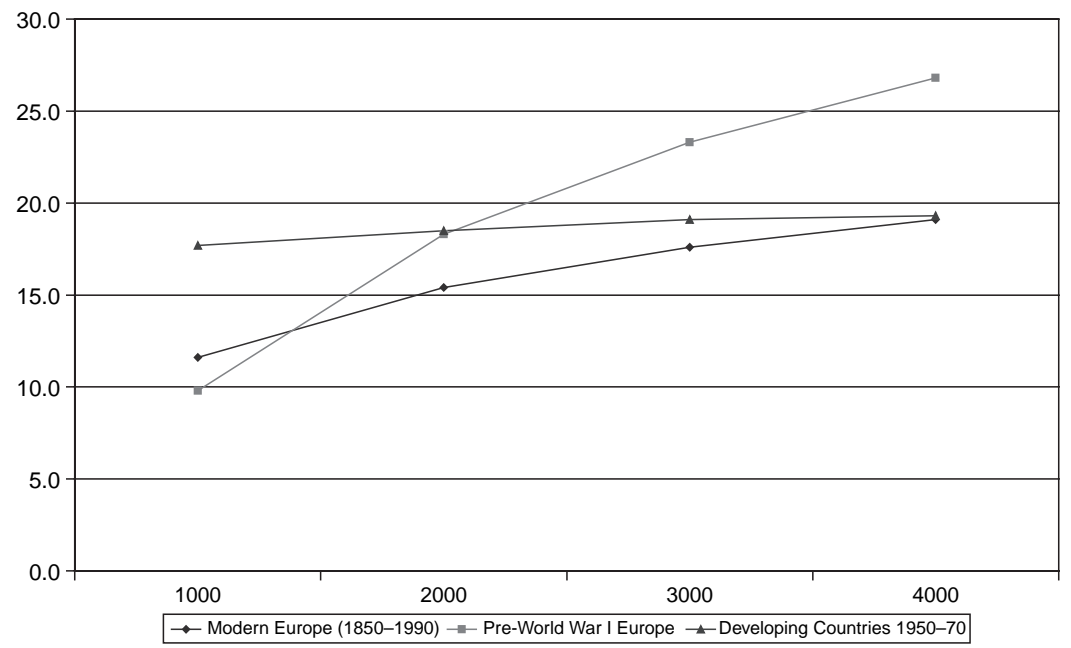

developing countries lends support to this hypothesis and shows a higher rate of natural increase in population (Figure 15) associated with the fall in mortality due to exogenous health improvements. ${ }^{48}$

Comparing growth elasticities for each structural variable at given income levels, or as income increases for different historical phases, is most illuminating. Values (in absolute terms) for both measures of elasticity for the pre-World War I era are shown in Table 6. The comparison with those for Modern Europe (Table 4) shows lower elasticity values for both the shares of investment and of industry in GDP in the income range $\$ 1,000-4,000$. It might be suggested that such a result is associated with the latecomers' catching up with the early starters and lends support to Gerschenkron's propositions a), b), and c). Nonetheless, larger growth elasticity for human capital formation and for openness, two ingredients of successful industrialisation, are exhibited in the pre-World War I patterns. Moreover, a much lower value of the growth elasticity for government consumption in early starters tends to confirm the idea of the government's stronger position in latecomers. Finally, the higher (absolute) value of the growth elasticity for the agricultural share in employment and for the urbanisation rate among the early starters reinforces the view of a less dynamic rural sector in the case of latecomers. It can be inferred, then, that Gerschenkron's stylised patterns of European development are not rejected by the empirical evidence provided here.

Gerschenkron's propositions would be better tested, perhaps, if instead of looking at 'adjusted patterns' that allow for differences between historical

48 Easterlin, R., How Beneficient is the Market? A Look at the Modern History of Mortality, European Review of Economic History, vol. 3, 1999: 3, 257-294; Riley, J.C., The Timing and Pace of Health Transitions Around the World, Population and Development Review, vol. 31, 2005:4, 741-764. 
Figure 11 Manufactured exports/GDP ratio in pre-1914 Europe, modern Europe and developing countries.

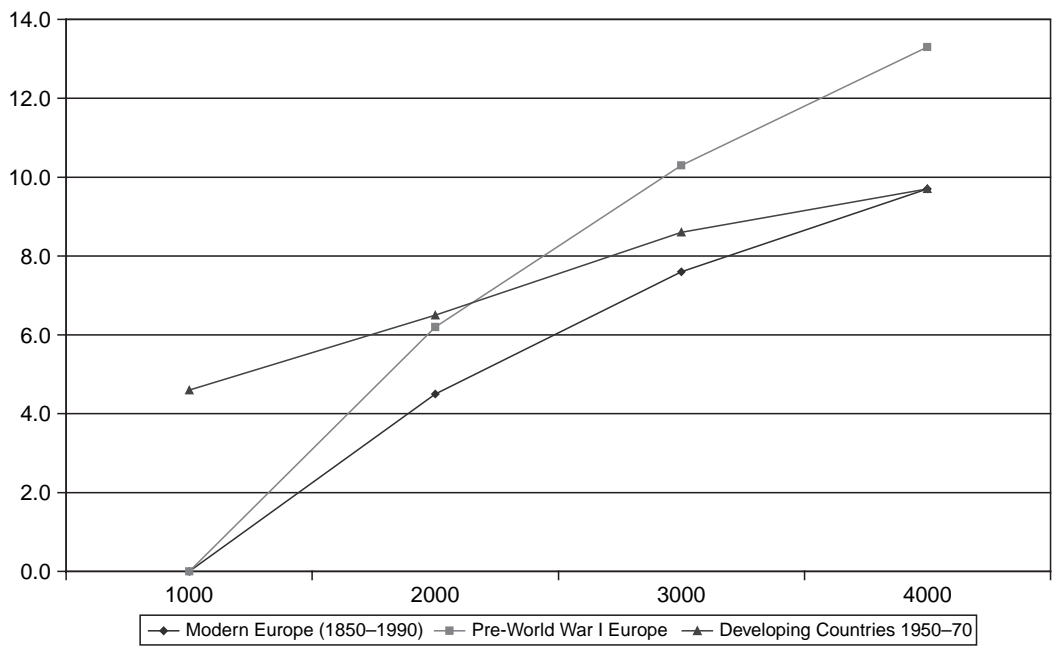

epochs, countries' trajectories were considered and, hence, 'country-adjusted patterns' were considered. ${ }^{49}$ We could draw, then, over the entire time span considered (1850-1990), a distinction between early starters and latecomers to industrialisation or, in modern development terminology, between Core and Periphery. ${ }^{50}$ The empirical use of these concepts presents obvious difficulties, namely, a country could have an early start but stagnate later, and ending up as part of the Periphery. As a compromise, we have carried out a quantitative exercise in which we arbitrarily split European countries between Core or early starters, and Periphery or latecomers, according to their relative position to Britain, the European leader up to the post-World War II years. Thus, those countries that, by 1950, had never reached a level of per capita income similar to that of the United Kingdom by 1913, were considered part of the Periphery, otherwise they were assigned to the Core. ${ }^{51}$ Unsurprisingly, the results obtained from comparing normal variations in development processes for Core and

49 Chenery \& Syrquin, Patterns of Development; Crafts, Patterns of development, and Branson et al., Patterns of Development, distinguish between country groups.

50 A word of caution is needed. The search for uniform features leads to a further division of countries into more homogeneous clubs that, in the end, might only represent alternative development strategies.

51 The following countries are included in the Periphery: Austria, Czechoslovakia, Finland, Greece, Hungary, Ireland, Italy, Norway, Portugal, Russia and Spain. Since only market economies have been considered, Czechoslovakia and Hungary have been excluded since 1950, and Russia since 1920. Patterns of development for Core and Periphery have been estimated through an econometric procedure identical to the one applied to the entire pool of countries and the econometric results for both single and adjusted patterns are available from the author upon request. 
Figure 12 Trade balance/GDP ratio in Pre-1914 Europe, modern Europe and developing countries.

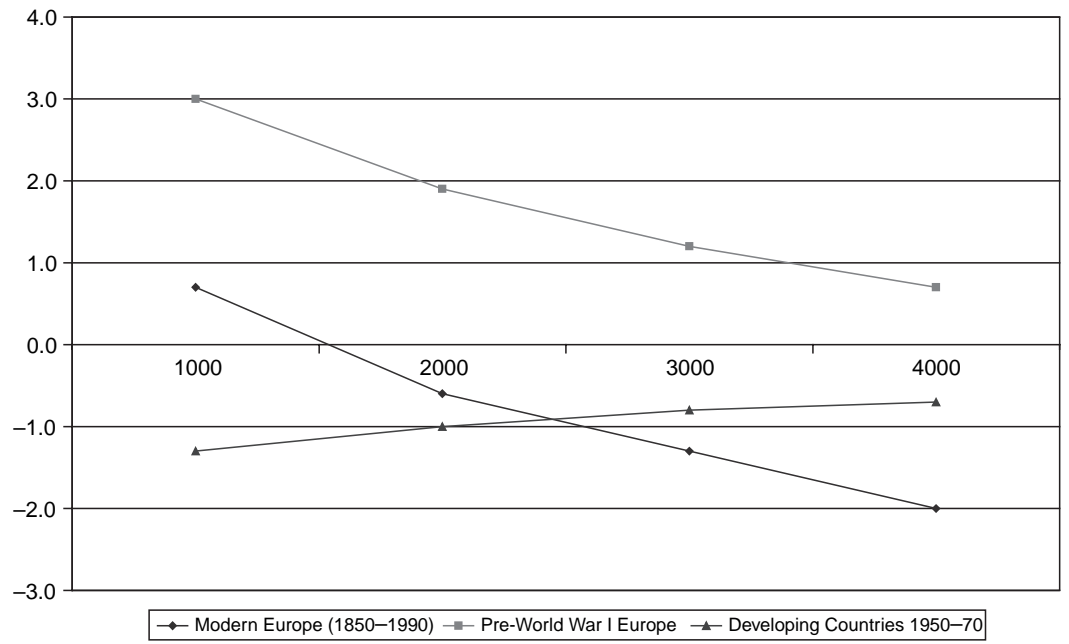

Periphery largely confirm those resulting from the contrast between the patterns of pre-1914 Europe and Modern Europe.

The main findings of the comparison between Core and Periphery, which tend to confirm Gerschenkron's views, can be easily summarised. ${ }^{52}$ Although at low income levels Core countries exhibit a higher rate of human and physical capital formation, such an advantage disappears as income rises, and Peripheral countries reach higher investment in physical and human capital. On the demand side, consumption remains higher in the Core, and its government consumption only catches up with the Periphery's at high income levels. On the supply side, the Core exhibits a smaller agriculture and larger industry and services, both in terms of output and employment. The agricultural productivity decline, relative to the economy's average, is larger in the Periphery, and the differential gap widens as income rises. The lagged shift of labour out of agriculture in the Periphery confirms Gerschenkron's intuition of a weaker agricultural contribution to economic growth among latecomers.

A higher degree of openness is observed in the Core while in the Periphery a larger (commodity) trade deficit appears, suggesting that as income grows, a larger inflow of capital (as percentage of GDP) takes place in the Periphery. Lastly, the demographic transition proceeds at a faster pace in the Periphery with a more rapid decline for mortality and, at higher income levels, population pressure is stronger in the Periphery.

52 The regression analysis and the development patterns over the $1990 \$ 1,000-12,000$ income range are available from the author upon request. 
Figure 13 Gross fertility (children per woman) in pre-1914 Europe and modern Europe.

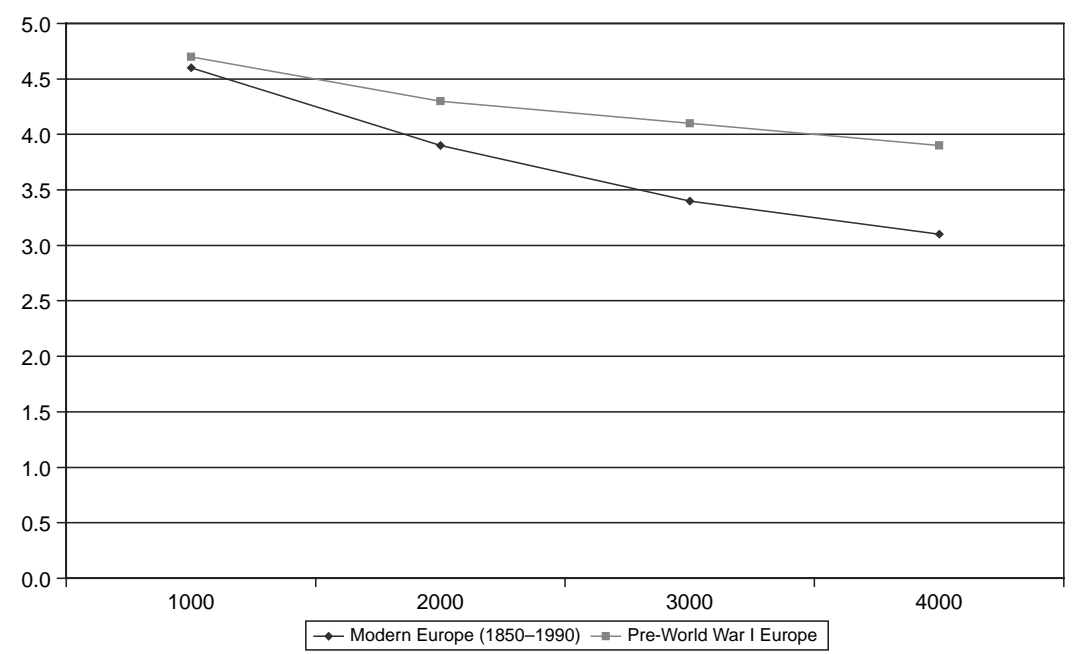

\section{Concluding Remarks}

In this paper European development patterns that associate structural change with variations in GDP per head and population have been examined in historical perspective. Europe provides a suitable scenario for testing regularities of growth since its countries share a common set of institutions, policies, and resource endowments. Some lessons can be derived.

Figure 14 Infant mortality rate (0/00) in pre-1914 Europe and modern Europe.

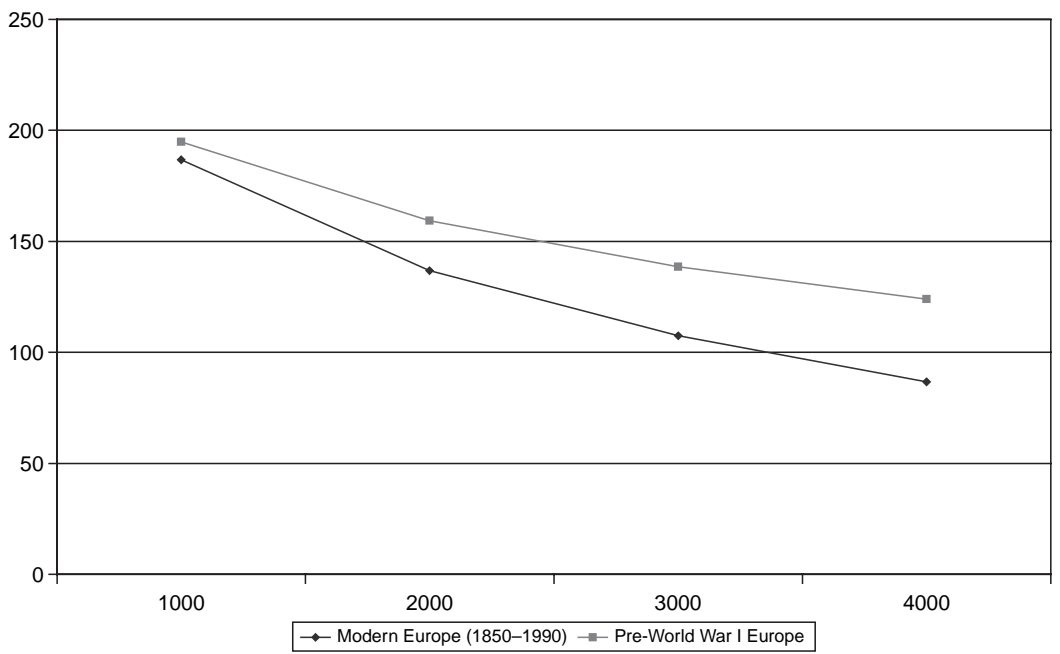


Figure 15 Natural population increase in pre-1914 Europe, modern Europe and developing countries $(0 / 00)$.

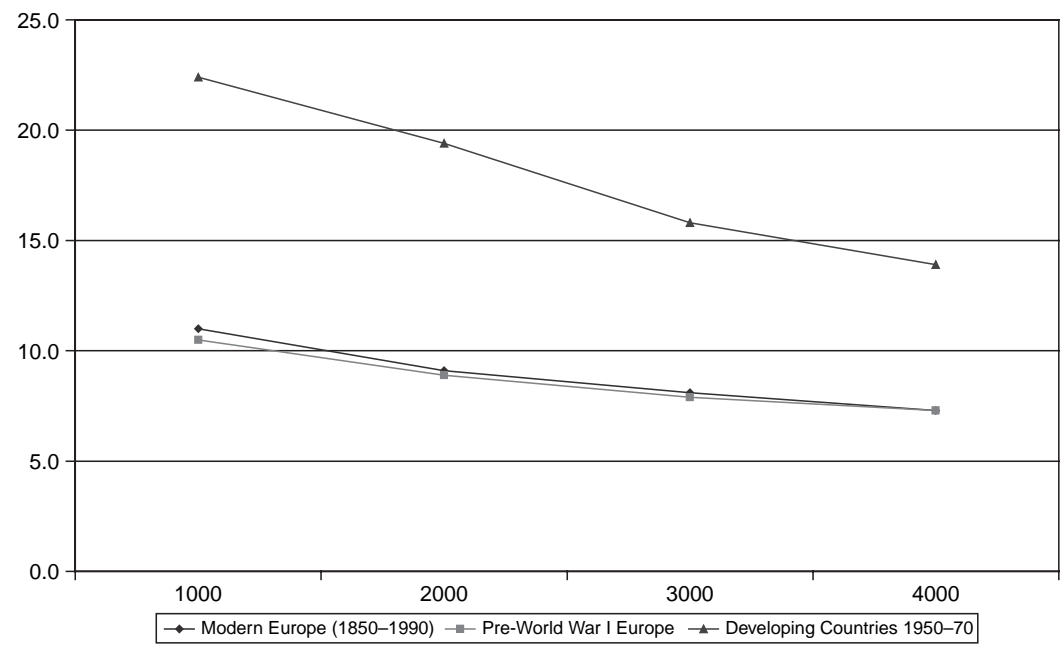

Patterns of structural change, constructed along the lines of Chenery and Syrquin's pathbreaking work, confirm the existence of a common set of development processes associated with rising per capita income for the whole of Europe. However, discernable development patterns for different epochs (observed with the adjusted patterns) confirm Gerschenkron's perception that early starters and latecomers followed their own paths of economic modernisation.

Differences between stylised features of development in early starters and latecomers raise interesting questions for further research. Are latecomers penalised by the fact that, at the same level of income per head, their investment and consumption shares in GDP are larger and lower, respectively, than for an early starter? Or do such differences result from a wider range of investment opportunities ? $^{53}$ Demonstration effects and the awareness that a higher rate of investment helps to catch up are perhaps behind such a differential. As Gerschenkron put it, 'the opportunities inherent in industrialization $(. .$.$) vary directly with the backwardness of the country'. { }^{54}$

Chenery and Syrquin reminded us that the analysis of the uniformity of development patterns constitutes a first step towards identifying the sources of diversity.$^{55}$ Each country's deviations from the estimated patterns at a given level of income per head and population are associated with country-specific characteristics such as resource endowments, institutions, and policies, and the

53 Besides, in recent times larger investment seems to be required to achieve economies of scale and scope in modern industry and services.

Gerschenkron, Economic Backwardness, 8. 
extent to which such a differential behaviour in accumulation, resource allocation, and demographic transition is behind the distinctive performance of latecomers deserves to be fully investigated within the framework of modern growth literature. This way Gerschenkron's idea that latecomers could substitute for missing prerequisites could be tested.

\section{Acknowledgements}

I am indebted to Steve Broadberry, Giovanni Federico, and Moshe Syrquin for encouraging me to go back to a research project I initiated sometime ago. I have received valuable comments and suggestions on a previous version of the paper from Steve Broadberry, Giovanni Federico, Tim Hatton, Jaime Reis, Albrecht Ritschl, Joan Rosés, Blanca Sánchez-Alonso, Isabel Sanz-Villarroya, James Simpson, and, especially, Patrick O'Brien. The usual disclaimer applies.

\section{Sources}

\section{GDP per head}

For each country, levels of Gross Domestic Product per capita expressed in 1990 Geary-Khamis dollars adjusted for purchasing power (OECD, National Accounts, 1960-1990. Main Aggregates. Paris: OECD 1992, vol. 1) have been projected backwards with volume series derived from historical national accounts. This aggregate covers the output of goods and services at market prices for the whole economy excluding income received from, or paid for, foreign investment. Data derive from the sources listed below. Otherwise they come from Maddison, World Economy.

Austria. GDP for Imperial (Habsburg) Austria is from Kausel, A., Österreichs Volkseinkommen 1830 bis 1913, in Geschichte und Ergebnisse der zentralen amtlichen Statistik in Österreich 1829-1979, Ed. Österreichisches Statistisches Zentralamt, Beitraege zur öesterreichischen Statistik, Heft 550. Vienna 1979, for 1850-1860, and from Schulze, M.S., Patterns of Growth and Stagnation in the Late Nineteenth Century Habsburg Economy, European Review of Economic History, vol. 4, 2000: 3, 311-340, for 1870-1913.

Belgium. Horlings, E., The Contribution of the Service Sector to Gross Domestic Product in Belgium, 1835-1990. Utrecht: Universiteit Utrecht 1997 (mimeo), 1830-1913; average of GDP estimates from Buyst, E., New GNP estimates for the Belgian economy during the Interwar period Review of Income and Wealth, vol.43, 1997: 357-375, (income and expenditure approaches) and Horlings, Contribution, (output), for 1925-1938.

Czechoslovakia. Lethbridge, E., National income and product, in Economic History of Eastern Europe, 1919-1975, II. Economic Structure and Performance Between the Two Wars, Eds. M. C. Kaser \& E. A. Radice. Oxford: Clarendon Press 1985, 532-597. 
France. Toutain, J.C., Le produit intérieur brut de la France, 1789-1990, Economies et Societés. Histoire Economique Quantitative, 1, 1997: 11, 5-136.

Finland. Hjerppe, R., Finland's Historical National Accounts 1860-1994: Calculation Methods and Statistical Tables. Jyväskylä: J.Y.H.L. 1996.

Germany. 1850-1890, Hoffmann, W.G., Grumbach, F. \& Hesse, H., Das Wachstum der Deutschen Wirtschaft seit der Mitte des 19.Jahrhunderts. Berlin: Springer 1965; 1900-1950, Spoerer, M., Weimar's investment and growth record in intertemporal and international perspective, European Review of Economic History, vol. 1, 1997: 271-297, and Ritschl, A. \& Spoerer, M., Das Bruttosozialprodukt in Deutschland nach den amtlichen Volseinkommes- und Sozialproduktsstatistiken 1901-1995, Jahrbuch für Wirtschaftsgeschichte, vol. 2, 1997: 2754. 1850-1900, GNP at market prices was obtained by re-scaling NNP with the GNP/NNP ratio for 1901-13, from Spoerer, Weimar's investment. 1850-1913, GDP at market prices was computed from the GNP estimates and from data on net factor payments abroad taken from Hoffmann et al., Das Wachstum, and Ritschl, A., Some National Accounts for Interwar Germany, 1925-1938, 1991 (mimeo). West Germany figures since 1950 include the Saar and West Berlin and figures for West Germany in 1950-55 had to be re-scaled by 8.6 per cent.

Greece. Kostelenos, G., Money and Output in Modern Greece, 1858-1938. Athens: Centre of Planning and Economic Research (KEPE) 1995, 1860-1938.

Hungary. Imperial (Habsburg) Hungary 1870-1913 at 1913 prices from Schulze, Patterns of growth and stagnation. Modern (Republic of) Hungary. 1913-1938, from Eckstein, A., National Income and Capital Formation in Hungary, 19001950, Income and Wealth, vol. V, 1955: 150-223, for the country as defined by the Treaty of Trianon (1919 reflated by 5 per cent to allow for GNP-NNP differences.

Netherlands. Smits, J.P., Horlings, E. \& van Zanden, J.L., Dutch GNP and its Components, 1800-1913. Groningen: Groningen Growth and Development Centre Research Monograph no. 5, 2000; den Bakker, G.P., Huitker, T.A. \& van Bochove, C.A. The Dutch economy 1921-1938: Revised macroeconomic data for the interwar period, Review of Income and Wealth vol. 36, 1990, 187-206.

Norway. Grytten, O.H., The gross domestic product for Norway 1830-2003, in Historical Monetary Statistics for Norway 1819-2003, Eds. Eitrheim, Ø., Klovland, J.T. \& Qvigstad, J.F. Norges Bank Occasional Papers no. 35, Oslo: Norges Bank 2004, 241-288.

Portugal. Lains, P., Growth in a Protected Environment: Portugal, 1850-1950, Research in Economic History, vol. 24, 2006: 121-163, 1850-1910; 1910-1955, Batista, D., Martins, C., Pinheiro, M. \& Reis, J. New Estimates of Portugal's GDP 1910-1958. Lisbon: Banco de Portugal 1997; 1955-1990, Pinheiro, M., Séries longas para a economia portuguesa pós II Guerra Mundial. I. Séries Estatísticas. Lisbon: Banco de Portugal 1997. 
Russia, (Imperial). Gregory, P., Russian National Income. Cambridge: Cambridge University Press 1982, 1885-1913.

Spain. Prados de la Escosura, L., El progreso económico en España, 1850-2000. Madrid: Fundación BBVA 2003.

Sweden. Krantz, O., Swedish Historical National Accounts 1800-1990. Aggregate Output Series. Umea: Umea University 1997(mimeo).

United Kingdom. Mitchell, B.R., British Historical Statistics. Cambridge: Cambridge University Press 1988.

\section{Population}

All figures are adjusted to refer mid-year and to take into account the territorial changes and are derived from Maddison, World Economy, and Mitchell, B.R., International Historical Statistics: Europe 1750-2000. New York: Palgrave Macmillan 2003. Nicolau, R., Población, salud y actividad, in Estadisticas Históricas de España. Siglos XIX-XX, Eds. A. Carreras \& X. Tafunell. 3 vols., Madrid: Fundación BBVA 2005, II, pp. 77-154, completes the figures for Spain.

\section{Demand Structure}

Domestic Investment, Private and Public Consumption in current prices, as percentages of GDP, are taken from Mitchell, International Historical Statistics; Flora, P., State, Economy and Society in Western Europe, 1815-1975. Frankfurt: Campus 1987; Maddison, A., A Long Run Prospective on Saving, Institute of Economic Research Faculty of Economics, University of Groningen, Research Memorandum, no. 443, 1990; and OECD, National Accounts, for most of the countries. Spanish figures are from Prados de la Escosura, Progreso económico. French figures were derived from Levy-Leboyer, M. \& Bourguignon F., L'économie Francaise au XIX ${ }^{e}$ siècle. Analyse Macro-économique. Paris: Economica 1985, up to 1913, and Carre, J.J., Dubois, P. \& Malinvaud, E., French Economic Growth. Oxford: Oxford University Press 1976, for the remaining years. Figures for Italy are from Ercolani, P., Documentazione statistica di base, in Lo sviluppo economico in Italia. Storia dell' economia italiana negli ultimi ciento anni, Ed. G. Fua. Milano: Franco Angeli 1978-81, 3 vols, III, pp. 388-472, for 1861-1890 and Rossi, N., Sorgato, A. \& Toniolo, G., Italian historical statistics, 1890-1990, Università degli Studi di Venezia, Dipartimento di Scienze Economiche, Nota di Lavoro, 92.18, 1992, for 1890-1990. In the case of Portugal, Batista et al., New Estimates, Pinheiro, Séries longas, and Cartaxo, R.J. \& Da Rosa, N.E., Series longas para as contas nacionais portuguesas 1958-1985, Banco do Portugal, Documento de Trabalho 15, 1986, were the references used. For the United Kingdom, Feinstein, C.H., National Income, Expenditure and Output of the UK, 1855-1965, Cambridge: Cambridge University Press 1972, and Mitchell British Historical Statistics.

\section{Output Structure}

Three major economic sectors are distinguished: agriculture (which includes forestry and fishing), industry (mining, manufacture, construction and utilities) and services (commerce, transport and communications, banking and private services, and public administration). Figures are provided as percentages of GDP 
at current prices. Most figures are taken from Mitchell, International Historical Statistics, Flora, State, Economy and Society, and OECD, Historical Statistics, 1960 1989. Paris: OECD 1991. In the case of Spain, Prados de la Escosura, Progreso económico. For France, Toutain, produit intérieur brut, and for Germany prior to World War I, Tilly, R., Capital formation in Germany in the nineteenth century, in Cambridge Economic History of Europe, Eds. M.M. Postan \& P. Mathias. Cambridge: Cambridge University Press 1978, VII, Part 1. pp. 382-441, and Fremdling, R., German National Accounts for the 19th and Early 20th Century. A Critical Assessment, Vierte Jahrschrift für Social- and Wirtschaftsgeschichtes, vol. 75, 1988: 339-355.

\section{Labour Allocation}

Distribution of working population by economic sectors. Three major economic sectors are distinguished: agriculture (which includes forestry and fishing), industry (mining, manufacture, construction and utilities) and services (commerce, transport and communications, banking and private services, and public administration). Figures are provided in the form of percentages of the total labour force from Bairoch et al., Working Population, Flora, State, Economy and Society, Mitchell, International Historical Statistics, and OECD, Labour Force Statistics, 1969-1990. Paris: OECD 1992. National figures were completed with Lains, Growth in a Protected Environment, and Nunes, A.B., A evoluçâo da estrutura, por sesos, da populaçâo activa en Portugal -um indicador do crecimento económico (1889-1981), Análise Social, vol. 26, 1991: 707-722, for Portugal; Toutain, produit intérieur brut, for France; Zamagni, V., A Century of Change: Trends in the Composition of Labour Force, 1881-1981, Historical Methods, vol. 44, 1987: 36-97, and Vitali, Vitali, O., Aspetti dello sviluppo economico italiano alla luce della ricostruzione della popolazione attiva. Roma: ISTAT 1970, for Italy; Prados de la Escosura, Progreso económico, for Spain.

\section{Foreign Trade}

Figures for exports and imports are from Bairoch, P., Commerce extérieur et développement économique de l'Europe au XIX ${ }^{e}$ siècle. Paris: Mouton 1976; Kuznets, S., Quantitative Aspects of the Economic-Growth of Nations, X: Level and Structure of Foreign Trade: Long-Term Trends, Economic Development and Cultural Change, vol. 15, 1967: 2; Mitchell, International Historical Statistics; OECD, National Accounts; OECD, Monthly Statistics of Foreign Trade. Paris: OECD 1992. For Portugal figures are derived from Nunes, A.B., Mata, E. \& Valerio, N., Portuguese Economic Growth 1833-1985, Journal of European Economic History, vol. 18, 1989: 291-330. Spanish figures are from Prados de la Escosura, Progreso económico, and Tena, A., Sector exterior, in Estadísticas Históricas de España. Siglos XIX-XX, Eds. A. Carreras and X. Tafunell. 3 vols., Madrid: Fundación BBVA 2005, II, pp. 573-644.

With respect to manufactured export figures, we used Maizels, A., Industrial Growth and World Trade World Trends in Production, Consumption and Trade in Manufactures. Cambridge: Cambridge University Press 1963; Batchelor, R.A., Major, R. L. \& Morgan, D. A., Industrialisation and the Basis for Trade. The National Institute of Economic and Social Research. Cambridge: Cambridge University Press 1980; Baldwin, R.E., The Commodity Composition of Trade: Selected Industrial Countries, 1900-1954 Review of Economics and Statistics, 40, 
1958, 50-71; Spiegelglas, Spiegelglas, S., World Exports of Manufactures, 1956 vs. 1937, Manchester School of Economics and Social Studies, vol. 27, 1959: 111139; Deutsch, K.W. \& Eckstein, A., National Industrialization and the Declining Share of the International Economic Sector, 1890-1959, World Politics, vol. 13, 1961: 267-299; Lamartine Yates, P., Forty Years of Foreign Trade. A Statistical Handbook with Special Reference to Primary Products and Under Developed Countries. London: George Allen and Unwin 1959; and Kuznets, Quantitative Aspects. Data for particular countries were completed with Prados de la Escosura, L., De imperio a nación. Crecimiento y atraso económico en España (17801930). Madrid: Alianza 1988, and Progreso económico; Tena, Sector exterior, for Spain; Davis, R., The Industrial Revolution and British Overseas Trade. Leicester: Leicester University Press 1979, and Schlote, W., British Overseas Trade from 1700 to the 1930's. Oxford: Basil Blackwell 1952, for United Kingdom; LevyLeboyer and Bourguignon, L'économie Francaise, and Toutain, J.C., Les structures du commerce extérieur de la France, 1789-1970, in La position international de la France Aspects économiques et financiers $X I X^{e}-X X^{e}$ siècles, Ed. M. Lévy-Leboyer. Paris, Editions EDHESS 1977, pp 53-74, for France; Eddie, S., The terms and patterns of Hungarian foreign trade, 1889-1913, Journal of Economic History, vol. 37, 1977: 329-358, for Hungary; Lains, P., Os Progressos do Atraso. Uma Nova História Económica de Portugal, 1842-1992. Lisbon: Imprensa de Ciencias Sociais 2003, for Portugal, and Capanna, A. and O. Messori, Gli scambi commercials dell'Italia con 1'estero. Roma:? 1940, for Italy.

\section{Education}

School enrolment refers to population attending primary and secondary school as a percentage of total population between the ages of 5 and 19. Figures are from Mitchell, International Historical Statistics, Flora, State, Economy and Society, World Bank, WORLD BANK (various years). Social Indicators of Development. Baltimore: Johns Hopkins University Press, UNITED NATIONS (various years). Statistical Yearbook. New York: U.N.; UNESCO (various years). Statistical Yearbook. Paris: Unesco. As regards Literacy, it represents the percentage of literate population (those who can read and write) with respect to total population above the age of 7 . In this case, figures are from Flora, P., Historical Process of Social Mobilization: Urbanization and Literacy, 1850-1965, in Building States and Nations, Eds. S.N. Eisenstadt \& S. Rokker. Beverly Hills, CA: Sage 1973, pp. 213-258; Mitchell, International Historical Statistics, and Hayami and Ruttan, International Historical Statistics. For Italy, Zamagni, V., L'offerta di istruzione in Italia 1861-1987: un fattore dello sviluppo o un ostacolo?, Università degli Studi di Cassino, Dipartimento Economia e Territorio, Working Papers 4, 1993; for Spain, Núñez, C.E., La fuente de la riqueza. Educación y crecimiento económico en la España contemporánea. Madrid: Alianza 1992, and Núñez, C.E., Educación, in Estadísticas Históricas de España. Siglos XIX-XX, Eds. A. Carreras and X. Tafunell. 3 vols., Madrid: Fundación BBVA 2005, I, pp.155244; and for Russia, Mironov, B.N., El efecto de la educación sobre el crecimiento económico: el caso de Rusia. Siglos XIX y XX, Revista de Historia Económica, vol. IX, 1991:165-197. 


\section{Urbanisation}

Population living in towns of 20,000 of inhabitants or more, as a percentage of total population. Figures are from Flora, Historical Process, and State, Economy and Society.

\section{Demographic Transition}

Birth rate and death rates are defined as the number of births and deaths per thousand of population. Infant mortality rate is the number of deaths per thousand births. Finally, fertility rate refers to the number of births per thousand of female population. Figures are from Chesnais, J.C., La transition démographique, Institut National d'Études Démographiques. Travaux et documents, Cahier no. 113. Paris: Presses Universitaires de France 1986, Mitchell, International Historical Statistics, World Bank, Social Indicators, and World Tables. Baltimore: Johns Hopkins University Press, and United Nations, Statistical Yearbook, New York: U.N., and for Spain, Nicolau, Población, salud y actividad. 